UNIVERSIDADE DE SÃO PAULO

ESCOLA DE ENFERMAGEM DE RIBEIRÃO PRETO

DEPARTAMENTO DE ENFERMAGEM PSIQUIÁTRICA E CIÊNCIAS HUMANAS

CYNTHIA DANIELA FIGUEIREDO DE SOUZA

Lazer e turismo na interface da saúde e da educação como meio de promoção de saúde mental do idoso 
CYNTHIA DANIELA FIGUEIREDO DE SOUZA

\section{Lazer e turismo na interface da saúde e da educação como meio de promoção de saúde mental do idoso}

Dissertação apresentada ao Programa de Pós-Graduação em Enfermagem Psiquiátrica da Escola de Enfermagem de Ribeirão Preto, USP para obtenção do título de mestre em Enfermagem Psiquiátrica.

Área de concentração: Enfermagem Psiquiátrica

Linha de pesquisa: Promoção de Saúde Mental.

Orientadora: Prof ${ }^{\mathrm{a}}$ Dr $^{\mathrm{a}}$ Sônia Maria Villela Bueno.

RIBEIRÃO PRETO 
AUTORIZO A REPRODUÇÃO E DIVULGAÇÃO PARCIAL OU TOTAL DESTE TRABALHO, POR QUALQUER MEIO CONVENCIONAL OU ELETRÔNICO, PARA FINS DE ESTUDO E PESQUISA, DESDE QUE CITADA A FONTE.

Catalogação na Publicação

Serviço de Documentação

Escola de Enfermagem de Ribeirão Preto

Universidade de São Paulo

SOUZA, Cynthia Daniela Figueiredo de

Lazer e turismo na interface da saúde e da educação como meio de promoção de saúde mental do idoso/ Cynthia Daniela Figueiredo de Souza; orientadora Prof $^{\mathrm{a}}$ Dr $^{\mathrm{a}}$ Sônia Maria Villela Bueno. - Ribeirão Preto, 2007.

100f.; il. $30 \mathrm{~cm}$.

Dissertação (Mestrado - Programa de Pós-graduação em Enfermagem. Área de Concentração: Enfermagem Psiquiátrica) - Escola de Enfermagem de Ribeirão Preto da Universidade de São Paulo.

1. Lazer. 2. Turismo. 3. Saúde mental. 4. Idoso. 
FOLHA DE APROVAÇÃO

CYNTHIA DANIELA FIGUEIREDO DE SOUZA

\section{Lazer e turismo na interface da saúde e da educação como meio de promoção de saúde mental do idoso}

Dissertação apresentada ao Programa de Pós-Graduação em Enfermagem Psiquiátrica da Escola de Enfermagem de Ribeirão Preto - USP para obtenção do título de mestre.

Área de concentração: Enfermagem Psiquiátrica

Linha de pesquisa: Promoção de Saúde Mental

Aprovada em:

Banca Examinadora:

Prof $^{\mathrm{a}}$. $\mathrm{Dr}^{\mathrm{a}}$

Instituição

Assinatura

Prof $^{\mathrm{a}}$. $\mathrm{Dr}^{\mathrm{a}}$

Instituição

Assinatura

Prof ${ }^{\mathrm{a}}$. $\mathrm{Dr}^{\mathrm{a}}$

Instituição

Assinatura 


\section{Dedicatórias}

Ao meu marido André Bandini, que idealizou, sonhou e colaborou intensamente para a realização dessa pesquisa. Sou imensamente grata a você. Meu Amor!

Ao Papai, a Mamãe, Cris, Débora e Sasha, eternas paixões!!!! 


\section{AGRADECIMENTOS}

Primeiramente gostaria de agradecer ao meu Deus, por ter me dado à alegria de ter uma família maravilhosa e ser dotada de saúde e capacidade para realizar um trabalho como esse. Que espero ser de utilidade para ajudar ao próximo de alguma maneira.

Ao meu pai José Maria, por ter sempre me encorajado e por ter sido um pai maravilhoso, que me ensinou a não ter medo de nada, quando o que estiver em pauta for o meu futuro e a minha felicidade.

A minha mãe Sonia, que sempre cuidou de mim, dando o seu melhor, colaborando imensamente com a minha educação e formação do meu caráter.

As minhas irmãs Cristiane e Débora, minhas eternas companheiras, meus amores. Que sempre dividiram comigo o que tinham de melhor.

Ao meu marido André, que me incentivou muito na busca desse ideal, fiel idealizador e colaborador de meus sonhos. Exemplo de respeito, competência e sucesso.

A minha amiga Andréia, que me ensinou o caminho das pedras.

A Prof ${ }^{\mathrm{a}} \operatorname{Dr}^{\mathrm{a}}$ Sônia Maria Villela Bueno, pra mim Soninha, minha gratidão por confiar em mim desde o primeiro momento. Muito obrigada pela dedicação e ajuda

Ao $\mathrm{CNPq}$, que financiou essa pesquisa. Aos freqüentadores do PIC, que aceitaram participar da pesquisa, especialmente a Tia Negrinha que me abriu as portas do grupo.

E também aos meus amigos, companheiros da Universidade, por terem me proporcionado momentos tão agradáveis e felizes, enfim a todos que de uma forma ou de outra colaboraram nessa caminhada. 
“Ninguém ignora tudo. Ninguém sabe tudo. Todos nós sabemos alguma coisa. Todos nós ignoramos alguma coisa. Por isso aprendemos sempre”. Paulo Freire 


\section{RESUMO}

SOUZA, C.D.F. Lazer e Turismo na Interface da Saúde e da Educação Como Meio de Promoção de Saúde Mental do Idoso. 2007. 100f. Dissertação (Mestrado) - Escola de Enfermagem de Ribeirão Preto, Universidade de São Paulo, Ribeirão Preto, 2007.

O lazer positivo tem uma função educativa importante e se caracteriza por um conjunto de atividades que pode nos levar à distração, recreação e ao entretenimento, a qual, todos nós, em um determinado tempo de nossa vida, nos dedicamos, aproveitando o tempo livre. Por vez, o turismo também faz parte dele, do qual podemos nos dedicar plenamente para promoção da nossa saúde física e mental. Deveras, o idoso carece de atenção especial neste sentido, por tratar-se de uma faixa populacional em crescimento, podendo encontrar nestas atividades um mecanismo para a obtenção da saúde mental, ao entregarem-se a elas, já que essas podem proporcionar interatividade e ser uma válvula de escape para os obstáculos e ou elementos estressores da vida cotidiana. Sensibilizados com essas questões objetivamos levantar com os idosos suas expectativas sobre lazer e turismo, tendo em vista o significado que eles vêm dando para a sua vida, para as suas aspirações, vontades e desejos no seu cotidiano existencial, que venha a contribuir com o nível de sua saúde mental. Planejar, executar e avaliar conjuntamente com eles, atividades educativas voltadas ao conhecimento e importância do lazer e do turismo, na vida deles, orientando-os para a promoção de sua saúde mental. Metodologicamente, desenvolvemos uma pesquisa qualitativa, humanista, mediatizada pela pesquisa-ação. Utilizamos duas técnicas para coleta de dados: a observação participante (diário de campo) e a entrevista com questões norteadoras (questionário). Trabalhamos com 26 idosos participantes de um núcleo de integração comunitária (PIC), da Prefeitura Municipal de uma cidade do interior paulista. A análise dos dados foi efetivada por categorização. Os resultados evidenciaram que os idosos pesquisados deram significados ao lazer relacionando-o aos aspectos sócio-culturais; desportivos; ao descanso; ao bem- estar e aos aspectos religiosos. Ao turismo especialmente como atividade de deslocamento (sóciocultural). Todos referiram que se distraem: conversando, passeando, viajando, dançando, ouvindo música, praticando atividades desportivas, semilazer, entre outros. Revelaram que gostam muito de: passear, ver amigos, viajar, etc. $\mathbf{E}$ que não gostam de atividades domésticas: passar roupa, usar computador, ficar muito parado e ou sozinho, etc. Atribuíram valor à felicidade e ao bem-estar, quando se distraem, revelaram que quando fazem isso sua cabeça fica muito bem e tranqüila. Referiram que viajam com a família e os amigos, mas pouco. Mencionaram ter medo da violência, referiram que ela prejudica seu lazer, atribuíram à oração e à educação como forma de saná-la. Destacaram como motivo de alegria e benção maiores a família a vida e a saúde, afirmando positivamente a importância ao núcleo (PIC) a que pertencem. Como sugestões do Programa Educativo, destacaram que queriam conhecer mais sobre a importância do lazer e do turismo para a promoção de sua saúde, o envelhecimento, ginástica, natação. No final das ações/intervenções educativas, referiram ter gostado muito do programa e ter adorado participar da pesquisa, sugeriram haver continuidade desse trabalho.

PALAVRAS CHAVE: lazer, turismo, saúde mental, educação e idoso. 


\begin{abstract}
SOUZA, C.D.F. Leisure and Tourism in the Interface of the Health and Education as a way of Mental Health Promotion to the Elderly 2007. 100f. Dissertation (Master Degree) Nursing School of Ribeirao Preto, University of Sao Paulo, Ribeirao Preto, 2007.

The positive leisure has an important educative function and show itself as a group of activities which may lead us to distraction, recreation and entertainment that every body, for some period of our lives, dedicate enjoying the free time. The tourism is also part of that, which we can quite dedicate ourselves promoting physical and mental health. In fact, the elderly phase needs special attention once it comprehends a piece of the population under continuous growth which may find through those activities a mechanism to obtain mental health once they can promote interactivity and be a way out from the barriers an/or stress factors of the quotidian life. Sensible to those questions, the goal is identify with elderly people their expectations about leisure and tourism considering that they are giving to their lives, aspirations, wills and wishes in their existential quotidian that came to contribute to the level of mental health. Plan, execute and assess together with them, educative activities related to the awareness and importance of the leisure and tourism in their lives, orienting them to the promotion of their mental health. Methodologically, we developed a qualitative research, humanist, through the method research - action. Two techniques were used to the data collection process: the participant observation (field daily) and the interview with directive questions (questionnaire). We worked with 26 seniors who are participants of a Communitarian Integration Nucleus (PIC), sponsored by the City Hall of a city in the countryside of Sao Paulo state. The data analysis was realized by categorization. The results emphasized that the elderly people who were interviewed gave meanings to leisure relating them to socio-cultural aspects, sportive, relaxing, wellness and to religious aspects. Specially to the tourism as traveling activity (socio-cultural).All of them have fun: talking, going out, traveling, dancing, listen sounds, doing sports, semi leisure, etc. They really like of: go out, meet friends, travel, etc. They don't like domestic activities: iron clothes, use a computer, stay without activities and/or alone, etc. They attributed value to the happiness and to wellness, when having fun, showing that when they do that, their mind gets well and relaxed. The majority prefers traveling with their families and friends. However, they travel not so frequent. They related being afraid of violence, referring that it perturb their leisure and appoint the religion and the education the solution for that.

They also emphasize the main reasons for happiness and bless are the family and the health, relating the Communitarian Nucleus (PIC) very positive for that as well. As a suggestion of the Educative program, they expressed interest in know more about the importance of the leisure and tourism to the promotion of their health, aging, exercising, swimming. At the end of the educative actions/interventions, they expressed that they liked the program and also be part of this study suggesting to deep on this research.
\end{abstract}

Key word: leisure, tourism, mental health, education and elderly. 


\section{RESUMEN}

SOUZA, C.D.F. Ocio y turismo en el interfaz de la salud y la educación como manera de la promoción mental de la salud del ancianos. 2007. 100f. Disertación (masters) - escuela del oficio de enfermera de Ribeirao Preto, universidad del Sao Paulo, Ribeirao Preto, 2007.

El ocio positivo tiene una función y una demostración educativas importantes sí mismo como grupo de las actividades que pueden conducirnos a la distracción, a la reconstrucción y a la hospitalidad que cada cuerpo, para un cierto período de nuestras vidas, dedica gozar del tiempo libre. El turismo es también la parte de eso, que podemos absolutamente dedicar promover salud física y mental. En hecho, la fase mayor necesita la atención especial una vez que comprenda a pedazo de la población bajo crecimiento continuo que pueda encontrar con esas actividades un mecanismo para obtener salud mental que él puede promover una vez interactividad y que sea una salida de los factores de la tensión de las barreras an/or de la vida quotidian. Sensible a esas preguntas, la meta es identifica con la gente mayor sus expectativas sobre el ocio y el turismo que consideran que están dando a sus vidas, aspiraciones, voluntades y deseos en su quotidian existencial que vino contribuir al nivel de la salud mental. El plan, se ejecuta y determina junto con ellos, las actividades educativas relacionadas con el conocimiento y la importancia del ocio y el turismo en sus vidas, orientándolas a la promoción de su salud mental. Metodológico, desarrollamos una investigación cualitativa, humanista, con la investigación del método - acción. Dos técnicas fueron utilizadas al proceso de la colección de datos: la observación de participante (campo diario) y la entrevista con las preguntas directivas (cuestionario). Trabajamos con 26 seniors que son participantes de un núcleo de la integración de Communitarian (PIC), patrocinados por la ciudad pasillo de una ciudad en el campo del estado de Paulo del sao. El análisis de datos fue observado por la clasificación. Los resultados acentuaron que la gente mayor que fue entrevistada con dio significados al ocio que los relacionaba con los aspectos socio-culturales, sportive, relajar, la salud y con los aspectos religiosos. Especialmente al turismo como actividad que viaja (sociocultural).All de ellos tienen diversión: hablando, saliendo, el viajar, bailando, escucha los sonidos, haciendo deportes, semi ocio, el etc. Realmente tienen gusto de: salga, resuelva los amigos, el recorrido, el etc. No tienen gusto de actividades domésticas: planche las ropas, utilice una computadora, la estancia sin actividades y/o solo, etc. Atribuyeron valor a la felicidad y a la salud, al tener diversión, demostrando que cuando hacen eso, su mente consigue el pozo y relajó. La mayoría prefiere el viajar con sus familias y amigos. Sin embargo, viajan no tan frecuente. Relacionaron estar asustada de violencia, refiriéndose que perturba su ocio y designa la religión y la educación la solución para eso. También acentúan las razones principales de la felicidad y las bendicen son la familia y la salud, relacionando el núcleo de Communitarian (PIC) muy positivo para ése también. Como sugerencia del programa educativo, expresaron interés adentro saben más sobre la importancia del ocio y del turismo a la promoción de su salud, envejecimiento, ejercitando, nadando. En el final del actions/interventions educativo, expresaron que tuvieron gusto del programa y también sean parte de este estudio que sugerían a profundamente en esta investigación.

Palabras clave: ocio, turismo, salud mental, educación y ancianos. 


\section{LISTA DE QUADROS}

DADOS SÓCIO-DEMOGRÁFICOS (PERFIL):

Quadro Aa-Dados de Identificação dos Idosos Pesquisados, segundo idade, sexo, religião, estado civil e Estado Civil

Quadro Ab-Dados de Identificação dos Idosos pesquisados, segundo profissão, renda mensal, filhos e netos

ANÁLISE DOS RESULTADOS REFERENTES ÀS RESPOSTAS DAS QUESTÕES PROPRIAMENTE DITAS, DO ESTUDO EM QUESTÃO:

Quadro 1 - Representação qualitativa das respostas das falas dos idosos pesquisados sobre as questões: $O$ que é Lazer? $O$ que é Turismo?

Quadro 2 - Representação qualitativa das respostas das falas dos idosos pesquisados sobre as questões: Você se distrai? Sim ( ) Não ( ) Como?

Quadro 3 - Representação qualitativa das respostas das falas dos idosos sobre as questões: $O$ que você mais gosta de fazer? $O$ que você menos gosta de fazer?.

Quadro 4 - Representação qualitativa das respostas das falas dos idosos pesquisados sobre a questão: Quando você se distrai com o que você gosta, como se sente?.

Quadro 5 - Representação qualitativa das respostas das falas dos idosos pesquisados sobre a questão: Quando se faz lazer e viaja, como fica a cabeça?.

Quadro 6 - Representação qualitativa das respostas das falas dos idosos pesquisados sobre as questões: Você tem viajado? Com quem? ( ) Familia ( ) Amigos ( ) Outros.

Quadro 7 - Representação qualitativa das respostas das falas dos idosos pesquisados sobre as questões: Você viaja com que frequência? （） Muito （） Pouco

Quadro 8 - Representação qualitativa das respostas das falas dos idosos pesquisados sobre as questões: Esse ano já viajou? E para o próximo ano pensa em viajar?

Quadro 9 - Representação qualitativa das respostas das falas dos idosos pesquisados sobre a questão: $O$ que significa amizade para você?

Quadro 10 - Representação qualitativa das respostas das falas dos idosos pesquisados sobre as questões: Como você tem visto a violência hoje? Isto prejudica o seu lazer?

Quadro 11 - Representação qualitativa das respostas das falas dos idosos pesquisados sobre a questão: $O$ que você faria para evitar esta violência?

Quadro 12 - Representação qualitativa das respostas das falas dos idosos pesquisados sobre as questões: Você gosta de música? Você gosta de dançar? 
Quadro 13 - Representação qualitativa das respostas das falas dos idosos pesquisados sobre as questões: $O$ que traz alegria para você? $O$ que você sonha para si?

Quadro 14 - Representação qualitativa das respostas das falas dos idosos pesquisados sobre as questões: $O$ que significa sua vida hoje?

Quadro 15 - Representação qualitativa das respostas das falas dos idosos pesquisados sobre: Livre para você falar o que quiser

\section{PROGRAMA EDUCATIVO:}

Quadro 1 - Representação qualitativa das respostas das falas dos idosos pesquisados sobre a questão: $O$ que você gostaria que eu falasse com você sobre o assunto Lazer e Turismo, como educação para sua saúde física e mental? $E$ de que forma poderíamos trabalhar juntos essa questão? 


\section{SUMÁRIO}

RESUMO

ABSTRACT

RESUMEN

LISTA DE QUADROS

APRESENTAÇÃO

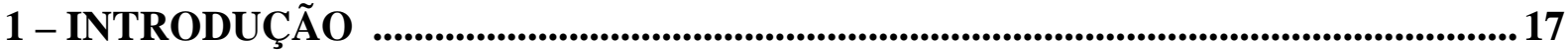

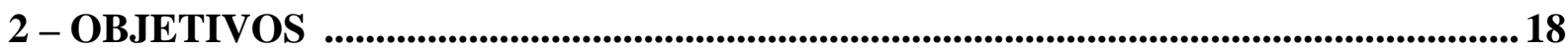

3 - MARCO TEÓRICO DE REFERÊNCIA....................................................................... 19

3.1 Saúde Mental e os Idosos ........................................................................................... 23

3.2 A Importância do Lazer e do Turismo na Promoção da Vida Humana ............ 27

4 - REFERENCIAL TEÓRICO-METODOLÓGICO........................................................ 39

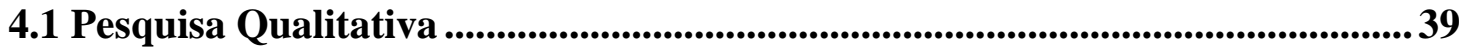

4.2 A Pesquisa-ação .................................................................................................................. 39

4.3 Coleta de Dados (Entrevista e Observação Participante) .................................. 39

4.4 Análise dos Dados .......................................................................................40

4.5 Desenvolvimento da Análise .......................................................................... 40

A - Levantamento do Universo Temático ............................................................40 40

B - Desenvolvimento da Atividade Educativa .......................................................... 42

5 - METODOLOGIA....................................................................................................................... 43

5.1 Tipos de Pesquisa.................................................................................................................. 43

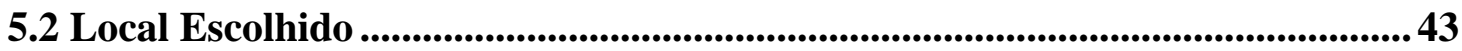

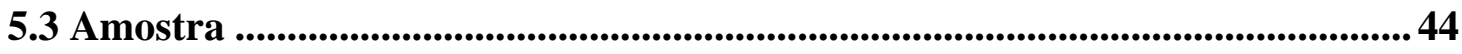

5.4 Técnicas para Coleta de Dados.............................................................................. 44

5.5 Normas Éticas ..................................................................................................4 44

5.6 Diretrizes para o procedimento de Análise dos Dados.......................................... 45

5.7 Desenvolvimento das Atividades Educativas da Pesquisa-Ação ......................... 45

5.8 Procedimentos (Passos) ............................................................................................46

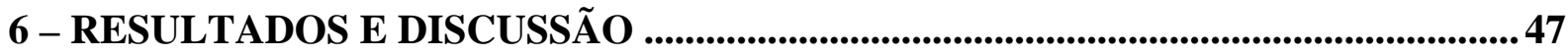

6.1 Observação Participante .................................................................................... 47

6.2 Dados Sócio-Demográficos.....................................................................................48 
6.3 Dados Relacionados às Questões sobre Lazer e Turismo ................................50

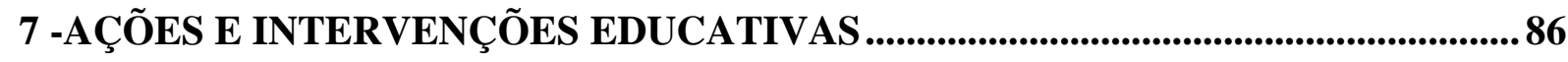

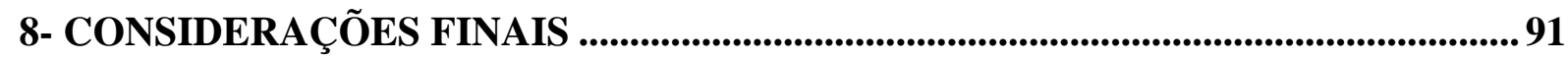

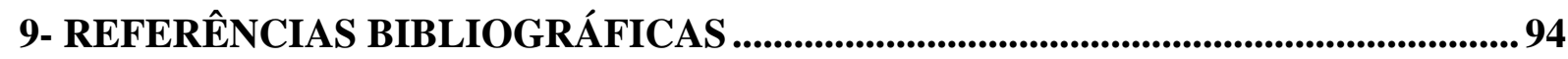

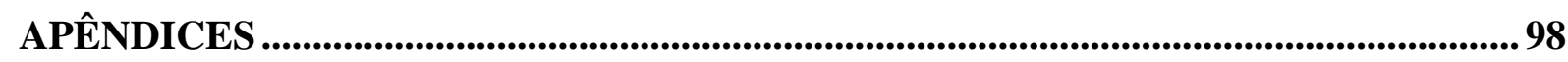

APÊNDICE 1 ...................................................................................................998

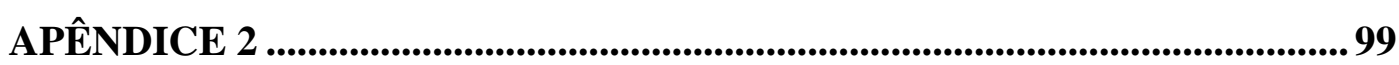

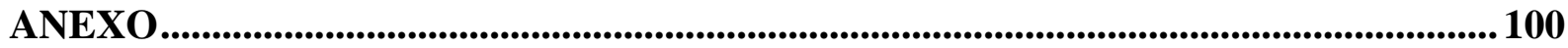

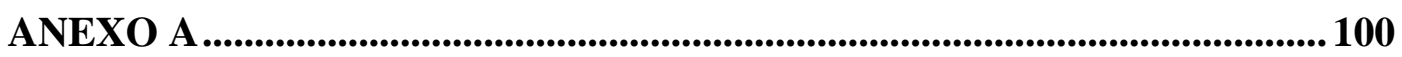




\section{APRESENTAÇÃO}

Durante a nossa Graduação em Turismo, que ocorrera no período de 1998 a 2002, muito nos motivava a significância da relação do turismo com o lazer e sua implicação na promoção da saúde mental das pessoas. Assim, ao longo desses anos, no cumprimento das disciplinas acadêmicas, adquirimos maior sensibilidade e mobilização para com esta temática, bem como fomos consolidando esta inquietação por meio de referenciais teórico-práticos sobre estas questões, possibilitando proximidades e identificações com o assunto nos permitindo portanto, atrelar o tema às questões da urbanização, da mudança do estilo de vida do homem pós-moderno e do seu comportamento, bem como das opções de lazer, e do verdadeiro significado destas atividades na vida das pessoas.

Vale ressaltar ainda que o contato com o turismo, como uma das mais diversas opções de lazer, sempre nos encantou pela oportunidade de entender uma vertente da promoção da vida humana ao se considerar a importância de se vivenciar de forma agradável e positiva, situações e experiências únicas; bem como, de se ter contato com o novo, o diferente, a liberdade, o bem estar e a felicidade. Então todos esses indicadores fazem parte do universo turístico. Assim, trabalhar nessa área de lazer e turismo significa para nós, uma das dimensões que contempla a otimização da vida humana.

Durante o período de Estágio Extracurricular, em Agência de Viagens e Turismo, pudemos perceber em nossas experiências empíricas a diferença de humor e do estado de espírito dos passageiros, antes do desenvolvimento dessa atividade, bem como no período de permanência no destino. E o depois, tínhamos os resultados emanados quando os mesmos retornavam repletos de alegria e animo. Percebíamos então a mudança deles para melhor, o que era extremamente visível. Começávamos deveras, a perceber, o quanto o turismo enquanto lazer poderia promover a saúde mental daqueles indivíduos, que na maioria das 
vezes, se apresentavam muito estressados, cansados e irritados, até mesmo alguns, com manifestações de perdas. Ao se deslocarem à viagem destinada, esse pessoal voltava mais calmos, mais serenos e conseqüentemente mais felizes.

Nos inserimos em um Programa de Iniciação Científica na Universidade, emergindo no mundo das pesquisas e da docência, com inclinação à carreira acadêmica. Daí, decidimos que a nossa temática no Mestrado, seria voltada para a triangulação, contemplando três pilares básicos lazer, turismo e saúde mental, tendo como pano de fundo, a Educação para a Saúde.

Para tanto, iniciamos uma Especialização, em nossa área, realizando estudos especiais, com um aprofundamento maior às questões do lazer aplicados à vida das pessoas. E essencialmente, buscando uma compreensão em relação à cultura do turismo na promoção da saúde. Essa experiência nos proporcionou amadurecimento frente aos nossos estudos e a confirmação do desejo à busca da pesquisa nesta área.

A nossa proposta para o Mestrado se concretizou naquele momento. Decidimos então, investir profundamente no assunto e pesquisar centros de excelência, onde fora possível ingressarmos e desenvolvermos nossos estudos na EERP/USP, no Departamento de Enfermagem Psiquiátrica e Ciências Humanas, inserindo em uma linha de estudo: Promoção de Saúde Mental.

A convivência com grupo de estudos e as atividades ali desenvolvidas, nos auxiliaram a consolidar o tema. Foi então, que optamos em trabalhar com idosos, por ser esta população alvo, de muita significância para nós, particularmente o que resultou a dissertação.

Este contingente populacional que vem crescendo ano a ano em nosso país, está muito vulnerável às diversas situações e problemas que os assolam, diariamente. Em contrapartida, é uma população que cada vez mais adere ao estilo de vida contemporânea, que está cada vez mais ávida ao prazer, ao bem-estar e ao despertar das sensações. É pois, através dessas atividades de lazer e turismo, que isto emerge de forma significativa. 
Sendo assim, chegamos finalmente à definição e a conclusão deste estudo, o que nos permitiu trabalhar neste processo, o desenvolvimento da abordagem qualitativa por meio da pesquisa-ação, embasando-nos nas idéias libertadoras de Paulo Freire, aplicadas à Educação para a Saúde, visando, portanto, a promoção da saúde física e, sobretudo mental do idoso.

Assim sendo, a oportunidade da investigação da influência destas atividades na promoção da saúde do idoso tornou-se possível graças ao levantamento de dados realizado, o que culminou com o desenvolvimento conjunto e interativo das ações/intervenções educativas, o que permitiu diálogo, reflexão e ação, a busca de tentativa de solução de problemas existentes emanados por eles frente às questões estudadas. Isto propiciou subsídios para um possível aumento do nível de sua saúde mental.

$\mathrm{Na}$ introdução e no marco teórico de referência procuramos trabalhar os referencias que contribuíram para o avanço do estudo.

Atribuímos espaço em destaque, para referencial teórico metodológico, por assim considerá-lo de grande importância para a nossa compreensão científica, neste processo. Descrevemos também a metodologia do estudo.

Os resultados tomaram uma dimensão peculiar, sendo apresentados os dados da observação participante, os dados referentes às questões sócio-demográficas (perfil), e a análise dos dados referentes às questões propriamente ditas ao estudo em questão e suas respectivas categorizações. Finalmente, fez-se a apresentação e a reflexão sobre a elaboração e a aplicação do Programa Educativo, resultando nas categorizações dos temas geradores culminou com as intervenções (envelhecimento, lazer, importância do lazer e turismo na saúde, os idosos e a saúde mental).

Finalmente, fizemos as considerações finais e a apresentação das referências bibliográficas. 


\section{INTRODUÇÃO}

A presente pesquisa tem como foco principal, o estudo da temática do lazer voltada ao turismo, como meio alternativo para a promoção da saúde mental dos idosos. Para tanto, fezse necessário trabalhar a educação para a saúde dessa população, considerando a importância da auto-estima, a distração, recreação e entretenimento como indicadores da valorização da vida humana.

Deveras de há muito, estudiosos do assunto vêm pesquisando na área do lazer e turismo, tendo em vista a relevância desses elementos na vida das pessoas. Daí, a significância do conhecimento das características, das possibilidades e das funções desta forma de descontração, assim como meios para o alívio do estresse, valorização da vida e da auto-estima, reinserção social e consequentemente para o aumento da sociabilidade e de educação para as pessoas em geral.

Em virtude do grande crescimento dos idosos na população geral, Veras (1994) destaca o seu interesse sobre esse assunto, convergindo com o nosso interesse para essa faixa etária do ciclo vital. Por esse motivo, procuramos investigar esse tema em apreço.

Mas obstante, a razão de se atrelar este assunto à saúde mental, deve-se ao fato da população idosa estar significantemente, vulnerável à senilidade, demandando meios alternativos para a melhoria da sua condição de vida. Sendo assim, torna-se necessária atenção e cuidados especiais aos idosos (PAPALÉO NETTO, 2007).

Para tanto, procuramos buscar dados na literatura, referentes ao turismo e ao lazer, procurando compreender melhor, a possibilidade de aplicação dos mesmos, para a promoção da saúde mental do idoso, tendo como base, a educação e a saúde preventiva, visando minimizar os problemas em questão.

Disto, acreditamos poder lançar mão a trabalhar um estudo efetivo e inovador, visando a contribuir para a otimização da vida do idoso, procurando assim desvendar e 
minorar os seus anseios, as suas preocupações, a sua realidade e a sua forma de viver, a partir de parâmetros e atividades diferenciadas das usuais.

Assim, procuramos analisar possibilidades que pudessem contribuir para esse estudo, vislumbrando-o como um ser humano integral, tendo em vista, considerá-lo como um ser humano mais digno, mais humano e mais feliz.

A partir do embasamento teórico sobre as amplas questões que se atrelam ao envelhecimento e tendo em vista as implicações biológicas e psicossociais do idoso, propomos, pois nesse estudo, trabalhar esse contingente populacional, buscando o seu significado enquanto pessoa, de forma crítica, criativa e reflexiva, buscando compreender as dimensões físicas, emocionais e socioculturais diante do lazer e do turismo e suas implicações na promoção de sua saúde física e sobremaneira, a sua saúde mental.

Diante desses pressupostos e dando embasamento à relevância deste estudo traçamos os seguintes objetivos.

\section{OBJETIVOS}

1- Levantar com os idosos, suas expectativas sobre lazer e turismo.

2- Identificar o significado que eles atribuem para as suas vidas e suas aspirações, tendo em vista a sua saúde mental.

3- Planejar, executar e avaliar conjuntamente com eles, atividades educativas voltadas ao conhecimento e importância do lazer e do turismo, tendo em vista a importância da utilização do lazer e turismo na promoção de sua saúde em geral. 


\section{MARCO TEÓRICO DE REFERÊNCIA}

O envelhecimento da população mundial é uma realidade (CARVALHO; GARCIA, 2003; PASCHOAL; FRANCO; SALLES, 2007; VERAS, 2007). Essa fase da vida humana caracteriza-se por uma série de alterações que todos enfrentamos com o passar dos anos (LIMA-COSTA; VERAS, 2003; RUIPÉREZ, LLORENTE, 2001).

O crescimento da população de idosos, ou seja, das pessoas com 60 anos ou mais, está ocorrendo em um nível sem precedentes (PASCHOAL; FRANCO; SALLES, 2007; VERAS, 2007).

Em 1950, eles somavam 204 milhões em todo o mundo. Em 1998, esse contingente populacional era representado por 579 milhões de pessoas. Já no Brasil, segundo o Censo de 1991, era representado por 10.722.705 de pessoas. Assim, mesmo nesse ano, a população idosa brasileira representava o total de 7,3\% da população. No Censo de 2000, a população de idosos, somava 14.536.029 de pessoas, representando 8,6\% da população, concluindo que o aumento do número de idosos fora de 4 milhões de pessoas (IBGE, 2000).

Entendemos que o Brasil passa por um processo denominado transição demográfica caracterizada por um processo gradual da diminuição de altas taxas de fecundidade e mortalidade. Isso não ocorreu e nem ocorre de forma uniforme, fatores como saúde e educação fazem com que esse processo aconteça de formas e maneiras diferentes em todo o mundo e no Brasil também (CARVALHO; GARCIA, 2003).

Essa mudança foi e é responsável pelas alterações na estrutura etária da população e seu envelhecimento. O aumento na proporção do número de idosos é denominado envelhecimento populacional, esse envelhecimento vem ainda acompanhado pelo aumento da expectativa de vida do idoso, a tendência observada é que o ser humano tem vivido mais anos. Fato que deve ser comemorado e gerenciado de uma maneira responsável, criando e reformulando políticas públicas voltadas as questões sociais e de saúde para atender de forma 
satisfatória essa conquista (PASCHOAL; FRANCO; SALLES, 2007).

Primeiramente, esse envelhecimento populacional se deu nos países desenvolvidos, de forma lenta, pois estes sempre tiveram taxas de fecundidade mais baixas que as brasileiras, mesmo no início desse processo, possuíam número maior de idosos, fazendo com que a distribuição da população, em faixas etárias, fosse mais eqüitativa. Foi possível também o amparo econômico e social dos idosos, devido ao grande poder econômico que os países em questão, possuem. (CARVALHO; GARCIA, 2003).

Quanto ao envelhecimento, ele é um processo natural da vida. Significa um aumento no número de anos vividos. Isto posto, depreende-se que o envelhecimento não é simplesmente um processo estanque. Está intimamente ligado à idéia de mudanças e alterações (BEAUVOIR, 1990).

Essas alterações podem ser de natureza biológica, o que se denomina Envelhecimento biológico, ou seja, a ocorrência de modificações físicas, que comprometem o funcionamento normal do organismo, sendo esse considerado um desgaste natural. Mas o envelhecimento é mais amplo do que alterações biológicas. Existe também, o chamado Envelhecimento Psicossocial, caracterizado por múltiplas perdas, que vão ocorrendo ao longo dos anos: como perda de status/posição social, que geralmente acomete os idosos após a aposentadoria; a pobreza, que dificulta as condições mínimas para a sua sobrevivência e sobremaneira, para a manutenção de sua vida social; medo e angústia que cercam essa fase da vida, como a perda de amigos e de entes queridos, entre outros. Essas condições, muitas vezes, acarretam a solidão e o isolamento social (RODRIGUES; DIOGO; BARROS, 2004; RUIPÉREZ; LLORENTE, 2001;).

Mais do que isto, o idoso expressa uma representação social, que foi construída e modificada através dos anos e das diferentes épocas e culturas. Na Antigüidade, a figura do idoso estava ligada à sabedoria e virtude. Porém, na Idade Média, essa figura foi praticamente 
esquecida, nesse período em que o Cristianismo ganhou muita força, a figura jovem de Jesus Cristo, no período feudal onde o vigor e a força física eram de extrema necessidade para as defesas territoriais, quando a imagem do idoso estava ligada à decadência. Já na Idade Moderna com o advento dos primórdios do Capitalismo (Mercantilismo) e, posteriormente, com a ascensão da burguesia, classe dominante naquele período, o idoso passa a ter papel primordial na família, pois teoricamente, por ter vivido mais tempo, tinha sido capaz de acumular mais bens e riqueza (BEAUVOIR, 1990; FROMER; VIEIRA, 2003).

Observamos que de meados do século XX à atualidade, ou seja, na idade Contemporânea, em tempos de Globalização e de grandes avanços tecnológicos, o “ter” tem sido muito mais valorizado que o "ser", abrindo, cada vez mais, um abismo entre os valores e a experiência do idoso em relação às novidades, a massificação das culturas e o consumismo, ideais que permeiam a sociedade atualmente. O envelhecimento geralmente, é visto como um processo negativo, carregado de preconceitos, estigmas e estereótipos impedindo a formação de uma identidade positiva do idoso, muitas vezes carregada de imagens ligadas à solidão, sofrimento, confinamento e morte.

Inúmeros progressos do desenvolvimento das sociedades como tecnologia e saúde são importantes para o aumento da longevidade humana e para a otimização da imagem do idoso. As sociedades começaram a prorrogar gradativamente, o envelhecimento de suas populações, a partir de conquistas na área da saúde preventiva e no desenvolvimento da indústria de medicamentos (PASCHOAL; FRANCO; SALLES, 2007).

No caso do Brasil, os idosos ganharam em termos quantitativos, o aumento da expectativa de vida, traduzido no aumento de sua sobrevida. No que se refere aos aspectos qualitativos, identifica-se uma melhoria em sua condição de vida, possibilitada graças aos avanços da medicina, da tecnologia e das conquistas sociais, tendo como exemplo, as políticas públicas para os idosos (FROMER; VIEIRA, 2003). 
Medidas para minimizar os problemas enfrentados pelos idosos, vêm sendo tomadas. Mas, não os esgota principalmente em países como o Brasil, que não tem recursos suficientes e o cumprimento total das leis para amparar o grande número de idosos brasileiros, que cresce a cada ano, conforme constatado pelos dados apresentados.

Levantar problemas de ordem social é fundamental para a questão do idoso. A igualdade de direitos deve ser respeitada, pois sua ausência impede que os benefícios sejam adquiridos por todos, sem exclusão. Em um país como o Brasil, que possui desigualdades sociais exorbitantes e uma taxa de pobreza considerável entre a população, o processo de envelhecimento possui características diferentes das ocorridas nos países desenvolvidos (PAPALÉO NETTO, 2007).

Levando em consideração que o idoso passa por múltiplas perdas, ele muitas vezes, se sente inferiorizado e marginalizado. Os problemas relacionados com o Envelhecimento Biopsicossocial, repercutem na vida do idoso, fazendo com que, por vezes, ele se sinta um fardo para seus familiares e amigos, levando-o ao isolamento social. Esse fato é um dos aspectos mais negativos para saúde física e mental do idoso (RUIPÉREZ, LLORENTE, 2001).

Portanto podemos depreender que o aumento dos idosos em países como o Brasil, nem sempre indicam melhoria e otimização de suas vidas. A realidade de problemas freqüentes na vida do idoso pode contribuir para a diminuição da auto-estima e ocorrência de problemas de saúde física e mental, visto as condições que esses indivíduos estão expostos.

Atividades, estimulação e a criação de meios que favoreçam a integração entre os idosos, podem contribuir para a manutenção de sua vida social, ou ainda para a sua ressocialização e reeducação, favorecendo a valorização de sua vida e de sua auto-estima. Estimular o desenvolvimento de atividades voltadas à distração, recreação e entretenimento, além de atividades culturais e desportivas, também pode representar um bom caminho na perspectiva de um envelhecimento saudável (BUENO, 1981). 
Estes benefícios podem ser encontrados em práticas de lazer e turismo, já que geralmente, os idosos possuem disponibilidade de tempo, podendo preenchê-lo com atividades que lhes possam dar prazer e proporcionar aumento da felicidade e interação social, promovendo a sua saúde física e principalmente a mental.

Os idosos precisam de um envolvimento mental saudável, portanto de estar bem, mentalmente. Isto é fundamental no processo de envelhecimento, ainda que se leve em consideração às perdas e os desgastes existentes nessa fase. Isto por si só, justifica a relevância deste estudo.

\subsection{Saúde Mental e os Idosos}

A saúde mental não deve ser entendida, simplesmente, como ausência de doença ou enfermidade. Ela deve ser entendida como um estado de equilíbrio entre o bem estar físico, mental e social. O indivíduo deve ser capaz de lidar com os problemas do dia a dia, bem como com o stress causado por eles. Deve haver atenção ao estilo de vida e sempre haver harmonia em todos os aspectos da mesma (WHO, 2001).

A compreensão da saúde mental foi constituída ao longo da história. Esta construção se entrelaçou à visão da loucura e dos transtornos mentais, que enfocaremos ainda que, sucintamente, na tentativa de ilustrar o quanto à saúde mental é fundamental em nossas vidas e prioritariamente, na vida dos idosos.

Por vezes, os transtornos mentais, geralmente, se caracterizam por uma combinação de idéias e emoções, comportamentos atípicos e problemas de relacionamentos com outras pessoas (MUNÕZ; KELLY, 1978).

É provável que a primeira notícia de transtornos do comportamento aconteceu na Mesopotâmia a 2.700 a.C. E que a insanidade era interpretada como causa provocada pelo demônio (NUNES; BUENO; NARDI, 2000). 
Na Antigüidade, o caráter mitológico e sobrenatural dos transtornos mentais era atribuído pelos gregos perdurando esse pensamento até a Era Clássica, quando Hipócrates procurou bases naturais para esses transtornos (BUENO, 1981; PESSOTTI, 1994).

Na Idade Média, com a censura e a ausência da busca das ciências durante este período, favoreceu-se o caráter religioso, atribuindo o poder às mãos da Igreja, apregoando os distúrbios como sendo ação do demônio (PESSOTTI, 1994).

No século XVIII, ocorreu a organização da Psiquiatria, a medicalização da loucura, especialmente na França e na Alemanha. Apareceram as classificações de Esquirol e Pinel, demonstrando também o sentimento de respeito ao indivíduo insano (NUNES; BUENO; NARDI, 2000).

Já no século XX (1948), a Organização Mundial de Saúde (OMS), publicava o Manual Internacional da Classificação de Doenças, Lesões e Causas de Morte, onde se incluiu pela primeira vez, os transtornos mentais (NUNES; BUENO; NARDI, 2000).

Em meados deste mesmo século, também acontecera o processo de desinstitucionalização, que teve início na Europa tendo como principal modelo: o Italiano. O movimento de desinstitucionalização visa eliminar a realidade e a cultura institucional (manicômio), bem como suas conseqüências: miséria e violência. Vem sendo então, adotado esse modelo em várias partes do mundo, mesmo que parcialmente. Essa mudança fez com que as condições dos indivíduos com transtornos mentais fossem revistas. A partir de então, vêm surgindo várias propostas reformistas (SARACENO; ASIOLI; TOGNONI, 1994).

Porém, ainda hoje, a realidade de um portador de transtornos mentais é delicada, e os idosos constituem grande parte deles. Em virtude do envelhecimento populacional, o número de idosos afetados no plano da saúde mental deve aumentar (WHO, 2001).

Por vez o preconceito é freqüente, em virtude de todo o histórico que cerca a assistência às pessoas em sofrimento psíquico, ao longo dos tempos. Por isso, muitos não 
procuram ajuda especializada e a maioria dos casos não é notificada. Alguns nem se dão conta que possuem transtornos mentais, principalmente os idosos e seus familiares.

Para que seja diagnosticada a ausência de saúde mental, em geral, mas particularmente no idoso, os sintomas devem ser recorrentes. Evidentemente, ao longo da vida, todos nós passamos por situações adversas que nos abalam, principalmente o nosso humor e os relacionamentos. Porém, logo essa situação se reverte, muitas das vezes, não indicando nenhum distúrbio. Todavia o diagnóstico deve ser preciso. As pessoas com algum transtorno mental são estigmatizadas pela sociedade. “Com o estigma vem à total exclusão e deterioração da imagem pública da pessoa que passa por aquela experiência”. (PUEL et. al. 1997, p. 33). Essa pessoa pode ser o idoso.

Em tempos de globalização e de sociedade de consumo, alguns aspectos sociais tais como: pobreza, desemprego, urbanização desenfreada e violência, podem ser considerados grandes estressores e estão, intimamente, ligados a casos de transtornos mentais, isto é, essas circunstâncias afetam severamente, a saúde mental dos indivíduos (WHO, 2001). São exemplos de transtornos mentais e de comportamento a esquizofrenia, a depressão, o retardo mental e os transtornos de personalidade, entre outros (NUNES; BUENO; NARDI, 2000).

Portanto na velhice, outras doenças podem somar-se trazendo efetivamente agravos graves. Muitas vezes, há impossibilidade de trabalho. Seus relacionamentos interpessoais ficam prejudicados, sem falar da estigmatização que ele passa a sofrer, isso porque acomete também, a família, que às vezes, tem que arcar com despesas, apoio e discriminação (BALLONE, 2005).

A depressão está cada vez mais associada à perda da saúde mental do idoso, em virtude das perdas eminentes com o envelhecimento, que por vezes, é uma manifestação freqüente de alteração psíquica pré-senil e senil, independente do estado de melancolia que muitos idosos apresentam, se caracterizando quando essa alteração é de maior intensidade, 
deixando evidente a distinção da melancolia (RUIPÉREZ, LLORENTE, 2001). Assim, a depressão no idoso, como em qualquer momento da vida, deve ser encarada como cuidado, atenção especial, precaução e seriedade, pois em alguns casos pode até levar a morte, por suicídio ou interferência no equilíbrio bio-psicossocial do idoso (MAIA; DURANTE; RAMOS, 2004).

Na busca da otimização da vida humana e do idoso a promoção da saúde e a promoção da saúde mental especificamente vêm sendo discutidas inúmeras vezes em diversos encontros internacionais, tais como a Carta de Ottawa (1986), Conferência de Adelaide (1988), Declaração de Jacarta (1997) entre outros. Nesses encontros foram discutidos e firmados compromissos quanto aos direitos sociais e ao desenvolvimento sustentável. Todos esses encontros compreendem basicamente que a promoção da saúde, é entendida como a capacitação dos indivíduos e da comunidade para alterar os determinantes de saúde. É importante que as pessoas e os idosos sejam capazes de mudar e/ou alterar seu modo de viver em prol da melhoria de sua vida. No caso específico dos idosos, preservar o contato social, atentar ao estilo de vida e ter equilíbrio entre o que se faz é de suma importância para a manutenção e a promoção da saúde, especificamente de sua saúde mental. (MOYSES; MOYSES, KREMPEL, 2004; WHO, 2003).

Assim, repensando a importância do desenvolvimento e da valorização de atividades socioculturais para o bem-estar do idoso, julgamos ser necessário a busca do entendimento sobre o significado do lazer e do turismo bem como implicações positivas destas atividades junto ao idoso, visando sobremaneira, a prevenção de sua saúde física e essencialmente a mental, tendo em vista, particularmente nessa faixa etária do ciclo vital. 


\subsection{A Importância do Lazer e do Turismo na Promoção da Vida Humana.}

\section{- Buscando Entendimento Sobre Lazer e Seus Benefícios ao Ser Humano}

O lazer teve seus primórdios na Antigüidade, sendo referenciado no chamado ócio grego, visto como tempo livre, no qual os mesmos davam grande importância a essas atividades, em contrapartida, às atividades de trabalho. O ideal de sabedoria era cultivado no ócio. Assim a Educação estava ligada a ele. Ficar ocioso para eles não era ficar sem fazer nada, conotação que a palavra mais tarde, acabou tendo por significado o desenvolvimento intelectual, contemplação, atividade mental e sensibilização (BACAL, 2003; BARRETTO, 1998). "Para Aristóteles a capacidade e o uso do ócio são à base da vida do homem livre”. (SANTOS FILHO, 2004, p. 157).

A possibilidade de ficar ocioso estava bastante ligada às questões relacionadas às classes sociais, pois só as mais abastadas se entregavam as atividades ociosas, pela necessidade do trabalho e cultivo de terras (BACAL, 2003).

Já na era Cristã, o ócio estava bastante ligado à idéia de contemplação, porém de ordem religiosa. O trabalho era visto como um meio dignificador do homem, pois era uma provação, tudo na vida era menos importante do que esperar pela vida eterna. Mas, o movimento da Reforma e, posteriormente, da Contra Reforma iniciado por Lutero, alterou o significado do trabalho, fazendo com que fosse abandonada a idéia do trabalho ligada à salvação e incorporada a idéia do trabalho ligada à valorização do tempo necessário, as atividades produtivas e, além disso, instaurou a idéia da realização do homem através do trabalho, fazendo que com que o ócio fosse mal visto (BACAL, 2003).

Esta situação se radicou ainda mais durante a Idade Moderna e com o advento da Revolução Industrial, pois a estimação ao trabalho ganhou mais força. Então, no século XVIII, com uma grande migração das áreas rurais para as áreas urbanas, a criação da produção em série, os trabalhadores vendiam aquilo que lhes pertenciam: sua força de 
trabalho. Com a separação do local de trabalho em relação sua própria residência, e com a necessidade de tempo disponível para o consumo dos bens produzidos, bem como para o descanso, em virtude do refazimento físico e mental do trabalhador, foram instituídos as férias e o descanso semanal (BARRETTO, 1998).

A partir de então podemos falar de uma divisão nítida entre tempo de trabalho e tempo livre. "O trabalho deixa de ser visto como castigo e passa a ser cultuado como virtude e necessidade oriunda do mundo moderno”. (SANTOS FILHO, 2004, p. 158). Faz-se necessário segundo o autor entendermos o desenvolvimento do trabalho para entendermos então as questões do lazer.

Atualmente a questão do lazer constitui uma série de atividades ligadas ao tempo livre das pessoas, sendo ainda o trabalho considerado como necessidade primeira das pessoas, ou ainda, podemos falar de outros compromissos de ordem religiosas, familiares e ou sociais, tendo no lazer o tempo de recuperação e portanto um espaço de realização humana (PAIVA, 2001).

Assim depreendemos que o lazer retrata um conjunto de atividades as quais os indivíduos realizam depois de se desligarem de seus afazeres e/ou obrigações. É também, uma entrega voluntária, incluindo a liberdade de escolha, criatividade, satisfação, passatempo, diversão e felicidade. Abrange pois, formas amplas de expressão (MARCELLINO, 2000).

“Prefiro entender o lazer como a cultura compreendida no seu sentido mais amplovivenciada (praticada ou fruída) no tempo disponível”. (MARCELLINO, 1990, P. 31).

O importante, como traço definidor, é o caráter de não obrigatoriedade e remuneração dessa vivência. As atividades de lazer de acordo com Dumazedier (2000) e Camargo (1999) podem ser divididas em: 
- Atividades Físicas: ginástica, esporte, caminhada, o que importa é a atividade física, seja ela desenvolvida em espaços técnicos ou não, é importante ressaltar o caráter associativo dessas atividades, que muitas vezes são realizadas em grupos.

- Atividades Manuais: atividades ligadas ao prazer de manipular, desde elementos da natureza até o concreto das grandes cidades. Ex: lavar o carro, artesanato, crochê, cuidar da horta, etc.

- Atividades Artísticas: Atividades ligadas a toda forma de arte, erudita ou não. Ex: cinema, literatura, festas tradicionais, teatro, etc.

- Atividades Intelectuais: Que visam à informação o conhecimento e a aprendizagem, seja por meio de leituras, palestras, filmes entre outros.

- Atividades Associativas: Trata-se do contato com o outro, entre amigos, familiares, vizinhos entre outros. Ex: Passeio com os filhos, jogos domésticos, freqüência em associações, etc.

- Atividades Turísticas: Nessa atividade de lazer, o interesse central dos indivíduos é a mudança de lugar, de paisagem, de ritmo e estilo de vida. Conhecer novos lugares e alterar a rotina. Ex: Todos os tipos de viagem de cunho turístico, que não estão ligadas a obrigações.

Isto posto, o lazer passa ser um meio privilegiado para o desenvolvimento interpessoal, expressa a idéia de liberdade, autonomia e liberação (BUENO, 1981).

Para o sociólogo francês, pai da Sociologia do Lazer, Joffre Dumazedier, o lazer passa então a ser entendido como:

O conjunto de ocupações às quais o indivíduo pode entregar-se de livre e espontânea vontade, seja para repousar, seja para divertir-se, recrear-se e entreter-se, ou ainda para desenvolver sua informação ou formação desinteressada, sua participação social voluntária ou sua livre capacidade criadora após livrar-se ou desembaraçar-se das obrigações profissionais, familiares e sociais. (DUMAZEDIER, 2000, p. 34). 
Por isto, o conjunto destas atividades passa a representar uma proposta inserida na vida dos idosos, que possuem a vantagem de ter a disponibilidade de tempo livre. Deveras hoje, o lazer, vem se constituindo no mais diversificado e mais extenso conjunto de atividades, para o idoso (FERRARI, 2007).

\begin{abstract}
O dimensionamento do lazer reside na possibilidade de suscitar atitudes ativas durante a utilização do tempo livre, como a participação consciente e voluntária na vida social, opondo-se ao isolamento e ao recolhimento social, e a exigência de um progresso social livre, pela busca, na utilização do tempo livre, de um equilíbrio, na medida do possível pessoal, entre repouso, a distração e o desenvolvimento contínuo e harmonioso da personalidade. (FERRARI, 2007, p. 248).
\end{abstract}

Sendo assim, o indivíduo idoso, por meio do lazer incluindo o turismo, pode ressignificar sua existência, de certa maneira que possibilite estar bem socialmente, visando à promoção da sua saúde mental. Este estar bem mentalmente, é importante em todas as fases da vida, mas sobretudo para o idoso, em processo de mudanças e alteração ás vezes graves, com perdas significativas, afetando tanto o âmbito físico, quanto mental e social.

Como estas atividades são diversas, os indivíduos idosos, podem optar por aquelas que mais lhes agradem e que melhor lhes convier. O nível de envolvimento também pode ser definido pelo mesmo. Pode ainda, contribuir para a promoção da saúde física e mental, dando verdadeiro sentido de vida. O lazer é de suma importância no desenvolvimento pessoal do ser humano. O homem precisa de lazer para voltar ao seu "eu” primitivo, para poder recompor a sua personalidade, em termos de promoção de saúde mental (BUENO, 1981).

As atividades que envolvem grupos facilitam a reinserção social do indivíduo. Essas atividades são capazes de incluir e de resgatar a auto-estima, à medida que são desenvolvidas. Transpondo para esferas exteriores, esses sentimentos, auxiliam no entorno dos praticantes, promovendo portanto a saúde mental (BUENO, 1981).

Considerando a questão do turismo como importante atividade de lazer na vida dos idosos e analisando esses pressupostos durante o envelhecimento, esse assunto certamente nos 
exige um maior investimento.

\section{- Buscando Entendimento sobre o Turismo e seus Benefícios ao Ser Humano}

O turismo teve antecedentes remotos na Antigüidade, com o deslocamento de povos como os Fenícios, Gregos e Romanos. Eles viajavam por diversos motivos tais como: peregrinações religiosas, festas de cunho esportivo (origem dos Jogos Olímpicos na Grécia), conquistas de novos territórios e novos povos. O Império Romano também propiciou condições para que seu povo pudesse viajar e explorar novos territórios. Nesse período foram construídas diversas estradas que ligavam Roma ao campo, as águas termais e ao mar. Os Romanos foram apontados como os primeiros a viajar por prazer (BARRETTO, 1998; IGNARRA, 2003; PAIVA, 2001).

Porém, essas viagens aconteciam em condições precárias, pois não havia meios de hospedagem e equipamentos estruturados para atendê-los, nem a intenção do lucro baseado nas viagens. Elas só podiam ser realizadas pelos homens livres. E os serviços eram prestados pela mão de obra escrava, não sendo estendidas às todas as classes sociais e nem às pessoas de todas as idades e ambos os sexos (BACAL, 2003).

Durante as invasões bárbaras que dominaram grande parte do Império, que veio a se dividir posteriormente, se tem notícia dos deslocamentos, por parte dos povos bárbaros, e de viagens para determinados rituais romanos (BARRETTO, 1998).

Já na idade média, com o feudalismo, o homem encontrava-se fixado a terra. A economia era basicamente agrícola e de subsistência. Somente os senhores feudais e os clérigos viajavam caso fosse imprescindível. Tivemos as cruzadas que colocaram muitos viajantes em todo o território europeu. Nesse período, os árabes foram viajantes insuperáveis, estenderam itinerários até o extremo oriente e em grande parte do território africano (AVIGHI, 2000; IGNARRA, 2003). 
No século XV, apareceu um novo tipo de viagem. A transoceânica, que teve como principais articuladores, Portugal e Espanha. Dava-se o início às grandes viagens de descobrimento de novos territórios, novos traçados geográficos e reafirmação de soberanias (PAIVA, 2001).

Durante os séculos XVI, XVII e XVIII, somente os muito ricos podiam viajar. Eles iam em busca de conhecimento e cultura. Essa experiência tinha caráter individualizado. Eram os chamados Grand Tour, longas viagens que eram realizadas pelos filhos da aristocracia, em busca dos mais diversos conhecimentos (URRY, 1990).

O século XVIII também presenciou um notável desenvolvimento da infra-estrutura turística com a proliferação de vários balneários por toda a Europa. Com o advento da Revolução Industrial, que se deu inicialmente, na Inglaterra, em meados deste século houve um grande êxodo rural, as cidades ficaram “inchadas”. A industrialização permitiu o aumento da sobrevida, em conseqüência de vários trabalhos ligados as questões sanitárias e projetos de urbanização. Por outro lado a Revolução Industrial instituiu a produção de bens de consumo em série. E os operários assalariados precisavam de tempo para consumir. Então foi instituído o domingo e posteriormente as férias (BARRETTO, 1998).

Surgia o Capitalismo Industrial contribuindo para o aparecimento das primeiras viagens organizadas e para o fortalecimento do turismo. Nesse período apareceram as chamadas classes médias: engenheiros, banqueiros, negociantes, médicos, entre outros. O espaço da moradia se diferenciara do espaço de trabalho e além de tempo para o consumo as classes médias e os operários passaram a necessitar de tempo para se dedicarem a atividades prazerosas (BARRETTO, 1998).

Além destes fatores, outros como segurança, salubridade, educação, evoluções dos meios de transporte e desenvolvimento dos meios de hospedagem fizeram com que o turismo se institucionalizasse. A viagem paga pelo viajante e planejada por terceiros era uma realidade 
(AVIGHI, 2000). É também no século XIX que surge a figura do turista, que é então aquele que procura prazer (ARAÚJO, 2001).

No início do século XX, o turismo já se destacava como uma atividade importante na entrada de divisas para equilibrar a balança de pagamentos, na geração de empregos e arrecadação de impostos. Essas evidências foram importantes para a diminuição do controle do trânsito internacional, nesse período (BANDUCCI, 2001).

Este tipo de atividade representou considerável crescimento após a Primeira Grande Guerra, ficando evidente a importância do automóvel para a sociedade desde aquela época. No período entre guerras, as férias remuneradas passaram a ser uma realidade para quase toda a Europa, permitindo o acesso da atividade turística para classes menos favorecidas. A Alemanha e a Itália foram os primeiros países a patrocinar integralmente, férias para sua classe operária (BARRETTO, 1998). Nesse período a família podia viajar em conjunto, favorecendo o deslocamento de todos, inclusive dos mais idosos.

No período que corresponde ao da Segunda Guerra Mundial (1939-1945) o turismo ficou praticamente, estacionado. O período pós-guerra é marcado por um ritmo acelerado nos avanços tecnológicos, especialmente dos meios de comunicação e de transporte. Essa evolução, aliada às conquistas sociais dos trabalhadores, (ex: férias remuneradas e décimo terceiro salário) fizeram com que o turismo criasse um ritmo acelerado nesse período. $\mathrm{Na}$ década de 60, o tema ganha destaque. Esse período também é marcado por um grande entusiasmo em torno do crescimento do turismo. A atividade cresceu $10 \%$ ao ano. O Banco Mundial e as Nações Unidas começaram a indicar este tipo de atividade lúdica para as nações do mundo inteiro, principalmente as nações então ditas em desenvolvimento (BANDUCCI, 2001).

Primeiramente o turismo chamou a atenção das ciências econômicas. Mais tarde, começou a ser estudado pelas ciências sociais (BANDUCCI, 2001). 
A partir da segunda metade do século XX, a estrutura das sociedades se transformou, com a inserção da informática e as mudanças culturais que ocorreram em todo o mundo. Assim, com o advento da Internet e da globalização, o turismo se transformou, e tem um papel diferente do que tinha anteriormente. Hoje, o turismo não é somente visto como uma atividade lucrativa, mas também, é visto como uma importante atividade de lazer, que é um dos seus principais motivadores. É de extrema importância para a sociedade atual, pois proporciona compensação e alternativa à vida cotidiana, que geralmente, é permeada por grandes fatores estressores, tais como: violência, pobreza, desigualdades sociais, entre outros que podem afetar o ser humano no plano da sua saúde física e mental, se constituindo em uma relevante atividade, que pode ser desempenhada por indivíduos idosos, preenchendo o seu tempo livre, de maneira rica e agradável (IGNARRA, 2003).

O turismo é do ramo das Ciências Sociais, podendo contar com a interface da educação e da saúde, na otimização da vida humana. A educação para o turismo dedica-se à organização de viagens, traduzindo em rico e profundo envolvimento humano.

Mas, o turismo pode também, ser capaz de unir e/ou separar mundos e idéias, difundir recursos e divisas, de construir ou mesmo destruir, dependendo de como vai ser experenciado. Por isso essas atividades devem ser planejadas e executadas com muitas responsabilidades, principalmente quando envolvem grupos que necessitam de cuidados especiais como os idosos (BENI, 1998).

O turismo é um fenômeno social. Envolve o deslocamento voluntário e temporário de pessoas, cada uma motivada de uma maneira à procura de recreação, descanso, cultura ou saúde, se deslocando de seu habitat para outro, no qual não exercem nenhuma atividade lucrativa, nem remunerada, gerando assim múltiplas inter-relações de importância social, econômica e cultural (DE LA TORRE, 1992). 
Esta definição revela a significância do turismo como fenômeno social, destacando as funções do lazer, recreação, descanso e cultura, comungando às idéias de Dumazedier (2000), bem como se consolida perante a Organização Mundial do Turismo (OMT), caracterizando o turismo como o deslocamento de pessoas de seu domicílio cotidiano, por no mínimo vinte e quatro horas, com a finalidade de retorno, sem o intuito de residência fixa e ou atividade lucrativa (BARRETTO, 1998).

Ainda para Bacal (2003, p.112):

Turismo é o conjunto de atividades e relações existentes nos deslocamentos temporais voluntários, realizado pelo afastamento da morada permanente- por diferentes motivos- com intenção de retorno, e a utilização total ou parcial dos bens e serviços oriundos para a satisfação dos viajantes.

Destacando a função da atividade turística na promoção da satisfação dos viajantes, Bacal (2003) ainda aponta a dificuldade em conceituar o turismo, já que a atividade envolve os bens tangíveis (atrativos turístico, infra-estrutura) e os bens intangíveis (sonhos, desejos e fantasias). Ressalta ainda a importância da autonomia e da liberdade na realização das viagens. Destaca que o turismo cumpre as três funções do lazer, preconizadas por Dumazedier (2000): função de descanso, de divertimento, recreação e entretenimento e a função de desenvolvimento.

Já para Urry (1990, p.52):

Turismo é uma atividade de lazer. [...] as relações de turismo surgem a partir do movimento e da permanência de pessoas em vários destinos; a jornada e a permanência ocorrem para e em locais diferentes de seus lugares habituais de residência e trabalho; turistas optam por ver lugares porque há uma expectativa, especialmente devido a devaneios e fantasias, de prazeres intensos.

Urry (1990), também destaca a idéia compensatória do turismo, pois são nas atividades de turismo, que vamos ao encontro com nosso “eu” interior, através da liberação de fantasias e realização de nossos desejos, que podem ser diversos, de acordo com a história individual de cada um. 
O turismo é uma opção de lazer, baseada em uma mudança de lugar (DUMAZEDIER, 2000). Por meio dele é possível realizarmos diversas atividades fora de nosso habitat, nos proporcionando algo único. Ainda como uma opção de lazer, o turismo é apontado como um grande aliado do bem-estar físico e psíquico na atualidade, podendo falar então, em saúde física e saúde mental, o que caracteriza “... benefícios psicofísicos tais como desinibição, descanso físico e mental e movimentação corporal” (BARRETTO, 1998, p. 89).

\section{- Lazer, Turismo e Sua Relação com o Idoso.}

Conforme podemos observar, o turismo e o lazer podem ser entendidos como veículos para a obtenção da saúde física e, sobretudo, da saúde mental das pessoas, particularmente, dos idosos. E, além disso, podem ser veículos ao mesmo tempo no campo da educação e saúde, tendo em vista sua importância para a otimização da vida e o exercício pleno da cidadania (BUENO, 2001).

Assim, depreendemos que o lazer e o turismo têm funções importantes para a manutenção da vida dos idosos. A primeira que trata do descanso, visando reparar os desgastes físicos e mentais; a segunda, que visa à recreação, divertimento e entretenimento, para aliviar o tédio, e para lidar com as frustrações do cotidiano. E a terceira, que aborda a questão do desenvolvimento pessoal, a criação de novas formas de aprendizagem e de lazer, destacando o caráter desinteressado das atividades desenvolvidas no tempo livre. (DUMAZEDIER, 2000). Assim, segundo esse autor:

É a função que permite uma participação social maior e mais livre, a prática de uma cultura desinteressada do corpo, da sensibilidade e da razão. Além da formação prática e técnica oferece novas possibilidades de integração voluntária à vida de agrupamentos recreativos, culturais e sociais, cria novas formas de aprendizagem voluntária a serem praticadas durante toda a vida e contribui para o surgimento de condutas inovadoras e criadoras. Suscita no indivíduo livre de suas obrigações profissionais comportamentos deliberadamente escolhidos e que visem ao completo desenvolvimento da personalidade dentro de um estilo de vida pessoal e social (DUMAZEDIER, 2000, p. 33). 
No caso dos idosos, a educação pelo lazer, trará a eles, possibilidades de desenvolvimento de estratégias para o enfrentamento da vida, no processo de envelhecer. As atividades recomendadas são: atividades de cunho cultural (teatro, música); atividades de socialização (viagens, vivência, dança, festa, troca de experiências); manutenção da independência (física, mental e social); desenvolvimento de atividades educacionais (palestras, oficinas de trabalho, informações) entre outros (BUENO, 1981; FERRARI, 2007).

Dentre estas atividades, vale ressaltar o papel do turismo, como uma atividade educativa fundamental para o idoso. Muitos descobrem mundos novos, por meio dessa prática. Durante as viagens, a troca de experiências, o cunho cultural das mesmas, o conhecimento da gastronomia e do artesanato local, a divulgação do folclore, o divertimento em atividades recreativas ou mesmo a própria contemplação e meditação, são exemplos de meios que fazem do turismo uma opção de lazer, que pode ser voltada para a educação e para a promoção da saúde física e mental.

O turismo é considerado um meio de entretenimento, mas pode ter também outras possibilidades, dependendo dos objetivos e motivações. Pode ser ainda, um mecanismo de aquisição de conhecimentos, por meio de uma educação alternativa, além do fator essencial de distração, recreação e entretenimento (BARRETTO, 1998).

Tanto no turismo, quanto às outras formas de desenvolvimento do lazer, existe a questão da sociabilidade, da reeducação e de uma outra maneira de encarar a vida e a realidade evidentes. Podendo trazer auxílio à população em questão, aumentando o seu refazimento físico e mental, bem como o prazer e a felicidade.

Vale destacar que por meio da educação, podemos tomar atitudes adequadas, criando valores positivos para a manutenção da vida. E isso pode ser trabalhado por meio do turismo e do lazer, atribuindo a essas atividades, meios favoráveis à saúde individual e/ou coletiva, particularmente do idoso. 
Deveras, depreendemos que o lazer, representado pelo turismo é de suma importância para todos, primordialmente, para os idosos, favorecendo meios alternativos para o aumento da auto-estima, valorização de si e do outro, dos aspectos de cidadania, entre outros medidores de saúde física e mental dos idosos, na comunidade. Isto por si só, justifica a relevância desse estudo, por estarmos em tempos de contemporaneidade, ou seja, com todas as características e demandas que os tempos nos incitam, demandando a busca de elementos que venham favorecer a otimização da vida, sobretudo dos idosos. 


\section{REFERENCIAL TEÓRICO METODOLÓGICO}

4.1 A abordagem qualitativa permite buscar um significado profundo, analisa as percepções do sujeito, possibilitando a compreensão à cerca do assunto, por meio da fala. Favorecendo o conhecimento de seus desejos, suas aspirações, valores e atitudes. É um tipo de abordagem que privilegia a vivência, o entendimento e a compreensão dos sujeitos pesquisados perante a temática abordada (MINAYO, 1992).

4.2 No presente caso a pesquisa qualitativa foi mediada pela metodologia da pesquisaação, que consiste em:

\footnotetext{
Um tipo de pesquisa social com base empírica que é concebida e realizada em estreita associação com uma ação ou com a resolução de um problema coletivo e no qual os pesquisadores e os participantes representativos da situação ou do um tipo de pesquisa social com base empírica problema, estão envolvidos de modo cooperativo ou participativo. (THIOLLENT, 2005, p. 16).
}

Trata-se de uma modalidade onde o pesquisador entra em um ambiente, se insere onde pretende investigar, possibilitando assim um caráter participativo. Possibilita também o levantamento de um problema, de uma inquietação, a partir daí, após o levantamento do problema, acontece à segunda fase, que consiste em uma ação educativa.

4.3 Esse tipo de metodologia pode apropriar-se da entrevista, na qual ocorre o levantamento dos dados da pesquisa propriamente dita, é o processo mais usual do trabalho de campo, é possível nesse momento obter dados objetivos e subjetivos. Também é feito o uso da observação participante, importante para captarmos situações e ou fenômenos que não são obtidos por meio de perguntas realizadas nas entrevistas, são observados diretamente na própria realidade (NETO, 1994).

A pesquisa-ação, ainda possibilita uma intervenção no grupo escolhido, de uma maneira consciente, na qual o pesquisador interfere no grupo, buscando um melhor 
entendimento por parte de seus membros, buscando sanar e ou minorar os problemas e conflitos encontrados.

Os sujeitos por meio da experiência vivenciada de uma maneira dialógica, problematizadora, conscientizadora, podem refletir a respeito do assunto, de sua postura, de suas atividades, possibilitando mudanças, construindo então, um processo educativo (FREIRE, 2006).

4.4 Para a análise dos dados temáticos faz-se necessário na pesquisa-ação, segundo Freire (1992), adaptado por Bueno (2001), aderir uma abordagem crítico social, que se fundamenta em aprender a ler o mundo e compreender o seu contexto. Com isso, a partir dos educandos/pesquisandos, é possível criar oportunidades para que os mesmos possam desenvolver e aperfeiçoar suas capacidades de compreenderem o mundo em que vivem (FREIRE, 1993).

Para tanto, o método de ensino-aprendizagem de PAULO FREIRE, que é um método ativo, dialogal e crítico, possibilita buscar conhecimento como os educandos/pesquisados pensam na realidade, o que pensam sobre ela, de modo que, ao tomar consciência, sejam criadores de cultura. Assim, trata-se de construir uma Educação transformadora, em que o elemento norteador é o diálogo do educador/pesquisador com os educandos/pesquisandos, numa relação horizontal (BUENO, 2001).

4.5 O desenvolvimento prático desse procede-se por meio de dois momentos, descritos previamente por Bueno (2001):

A. Levantamento do Universo Temático - Descrição e interpretação da situação dos sujeitos pesquisados. Identificação das suas necessidades, bem como dos conhecimentos prévios por eles demonstrados. O Universo Temático é o conjunto de temas geradores, na qual a investigação desse Universo implica numa metodologia dialogada e 
conscientizadora (FREIRE, 1993). A organização da análise do universo temático segue as seguintes fases:

1- Levantamento dos Temas Geradores. Esta fase, segundo Freire (1992), culmina com a busca de resultados muito ricos para os pesquisadores, não só pelas relações que travam, mas pela busca da temática do pensamento dos homens, pensamento este, que se encontra somente no meio deles, no seio de sua cultura. Busca-se, portanto, temas significativos com os participantes desse processo. Sendo o ponto de partida do processo de Educação, que os situará no mundo onde vivem, fazendo com que os mesmos compreendam o sentido de suas atividades, que os instiguem a tomar posturas positivas em suas atitudes, uma medida educativa do tipo libertadora. Como refere Freire (1993), o tema gerador é o pensamento do HOMEM sobre a realidade e sua ação sobre a ação para esta realidade que está em sua práxis. Essas observações e a emissão dos significados e do pensamento acontecem no ambiente trabalhado.

2- Organização do Material da Coleta de Dados. Registra-se o resultado da emissão dos significados e do pensamento dos sujeitos pesquisados, captados através da observação participante e/ou da aplicação de um instrumento, possibilitando interpretação e seleção dos assuntos centrais, conforme sugere Freire (1992). Processa-se a leitura detalhada das observações participantes e das respostas emitidas pelos sujeitos pesquisados. São elaborados os recortes do texto, criam-se as categorias, através da seleção das frases e/ou palavras repetidas com maior freqüência ou colocadas com mais ênfase pelos sujeitos participantes do estudo e que são passíveis de serem trabalhadas na atividade educativa.

3- Seleção e Codificação de Palavras e Frases Registradas/Emitidas. Selecionam-se em ordem definida, algumas palavras e/ou frases que possam ser agrupadas pela riqueza temática, surgem então os temas geradores. 
4- $\quad$ Síntese de palavras e Frases Selecionadas. Selecionam-se e são também codificados os temas geradores, são agrupadas, todas as palavras e frases relacionadas ao tema gerador, reúnem-se os grandes temas.

5- Ordem dos Temas Geradores. Ordenam-se os temas geradores, pedagogicamente, numa seqüência lógica no planejamento e execução das atividades educativas estabelecidas.

\section{B. Desenvolvimento das Atividades Educativas da Pesquisa-Ação}

1- Planos de Ensino Relativos aos Temas Geradores. Elaboram-se o planejamento de ensino, considerando os temas geradores.

2- Desenvolvimento da Ação Educativa. O projeto de investigação, a Pesquisa-Ação, pressupõe uma relação de participação entre pesquisando e pesquisador. Sendo assim, juntos, são refletidos os temas em questão. Manifestações verbais e participação ativa dos sujeitos refletem a eficácia da ação educativa implementada.

3- Avaliação do processo. Após abordagem adequada das ações propostas e implementadas deve acontecer à avaliação desse processo, realizada conjuntamente com os sujeitos pesquisados, favorecendo a compreensão real do significado da atividade realizada. 


\section{METODOLOGIA}

5.1 Tipo de pesquisa: Trata-se de uma investigação de natureza qualitativa, fundamentada em uma visão humanística, que se preocupa com uma série de significados que permeiam a vida social (MINAYO, 1992).

5.2 O local escolhido foi um núcleo do PIC (Programa de Integração Comunitária), que é desenvolvido pela Prefeitura Municipal de Ribeirão Preto em parceria com a Secretaria Municipal da Saúde, do mesmo município. Esse programa existe na cidade desde 1993, foi idealizado por uma pesquisadora da Escola de Enfermagem de Ribeirão Preto, objetivando a promoção de saúde. Nesse núcleo são realizadas atividades direcionadas a mudança do estilo de vida e desenvolvidas atividades de lazer e turismo (PALHA; LIMA; MENDES, 2000).

O núcleo escolhido para esse estudo foi o da Vila Virgínia, que realiza suas atividades as terças e quintas-feiras semanalmente. A escolha do núcleo foi embasada em dois aspectos considerados: por ser um dos grupos mais sólidos do programa e por sua localização mais centralizada, que possibilitou trabalhar com um grupo mais homogêneo, com poucas diferenças sócio-econômicas.

Primeiramente, iniciamos o contato com o responsável pelo grupo, expondo os objetivos do trabalho e as nossas diretrizes. Em razão disso, solicitamos permissão para a realização da pesquisa.

Uma vez aprovada a possibilidade da realização deste estudo nesse local, iniciamos a primeira fase, caracterizada pela entrada de campo, sendo possível à aproximação do pesquisador/pesquisando, apresentamos os nossos objetivos. Isto favoreceu a interação entre ambas as partes, o que sabemos ser de extrema importância, esse vínculo entre pesquisador e o grupo pesquisado, visando melhor conhecimento e compreensão do cotidiano do mesmo, seus dilemas, dúvidas e aspirações (NETO, 1994). 
5.3 A amostra foi obtida entre os participantes do PIC. Foram incluídos no estudo, idosos que possuem 60 anos ou mais. Esse núcleo conta com um número de participantes oscilante entre quarenta (40) e cinqüenta (50) usuários. Dentre esses, trabalhamos com 26 sujeitos que demonstraram o desejo de participar da pesquisa disponibilizando e assinando o termo de Consentimento Livre e Esclarecido (Apêndice 2).

5.4 As técnicas adotadas para a coleta de dados foram à entrevista, realizada individualmente, face a face com o sujeito, apropriada de um instrumento (questionário). E a observação participante que nos permitiu registrar os dados do local e dos próprios sujeitos do estudo, para melhor compreender aquela realidade. Para isso, usamos o diário de campo.

Assim sendo, foram aplicados questionários referentes às temáticas relacionadas ao lazer, turismo, saúde mental e algumas inquietações que permeavam a vida dos idosos. Para a aplicação do mesmo, realizamos um instrumento piloto, para testagem e validação, o que culminou com o questionário definitivo. (Apêndice 1).

A observação participante favoreceu a aproximação plena, na qual os sujeitos puderam ser observados aleatoriamente, em seu cotidiano, no desempenho de suas funções diárias. Desde o primeiro encontro, efetivamos as anotações por meio da observação participante. Também foi elaborado um material obtido por meio de fotografias, que foram realizadas durante os encontros do grupo.

5.5 As normas éticas foram adotadas de acordo com a resolução de número 196, do Conselho Nacional de Saúde. No desenvolvimento deste estudo, foram consideradas as diretrizes e normas regulamentadoras de pesquisas envolvendo seres humanos. Foi encaminhado ao Comitê de Ética da Escola de Enfermagem de Ribeirão Preto (EERP/USP), o pedido de apreciação do projeto de pesquisa foi aprovado e posteriormente após a obtenção do parecer favorável do CEP ( $\mathrm{N}^{0}$ 0728/2006); disponível no (Anexo A), demos início à pesquisa e à coleta de dados. 
Inicialmente, as pessoas foram abordadas, e recebendo as devidas informações sobre a pesquisa, evidenciando os objetivos propostos do estudo seguido da solicitação para cada um deles.

A maioria se interessou sobre o assunto e grande parte deles resolveu aderir à pesquisa, desde o primeiro momento.

A nossa presença foi sempre bem aceita durante todo o período em questão.

Antes da realização da entrevista e da aplicação do instrumento, esclarecemos sobre o Termo de Consentimento (Apêndice 2) que foi lido, explicado e posteriormente, solicitado à assinatura dos mesmos, bem como lhes fornecemos uma cópia, constando os nossos contatos, para eventuais dúvidas.

\subsection{Diretrizes para o procedimento de Análise dos Dados:}

- Levantamento do Universo Temático.

- Levantamento dos Temas Geradores.

- Organização do Material da Coleta de Dados (Elaboração das Categorias).

- Seleção e Codificação de Palavras e Frases Registradas/Emitidas.

- Síntese de palavras e Frases Selecionadas.

- Ordem dos Temas Geradores.

\subsection{Desenvolvimento das Atividades Educativas da Pesquisa-Ação:}

- Planos de Ensino Relativos aos Temas Geradores. 
- Desenvolvimento da Ação Educativa.

- Avaliação do processo.

\subsection{Procedimentos (Passos)}

- Solicitação para a realização da presente pesquisa junto a Secretaria Municipal da Saúde da Prefeitura de Ribeirão Preto.

- Encaminhamento do Projeto ao Comitê de Ética e Pesquisa da EERP/USP. (Anexo A).

- Realização da observação participante, para melhor conhecimento do sujeito e da realidade do local. Foram realizadas durante os encontros do PIC no núcleo (terças e quintasfeiras).

- Aplicação do instrumento. Foram realizadas as entrevistas usando um questionário após os encontros do PIC (terças e quintas).

- Desenvolvimento das ações/ intervenções educativas no local, de forma grupal (planejamento, ação e intervenção conjuntos). Foi realizada no Centro Social Urbano (CSU)Vila Virgínia, local onde os idosos freqüentavam para a realização das atividades do PIC. Aconteceu especificamente, em um salão coberto, onde pudemos nos reunir com maior conforto e tranqüilidade para a realização das atividades, trabalhando questões voltadas ao lazer, ao turismo e ao envelhecimento. Nos momentos educativos (plano de ação) elucidamos dúvidas, trocamos informações e construímos conhecimento conjuntamente com eles, e buscamos uma melhor compreensão da importância dessas atividades para a saúde mental dos idosos.

- Avaliação do processo. Foi realizada de forma aberta, participativa, além de ter sido uma maneira muito positiva, conforme eles mesmos referenciaram o tempo todo. 


\section{RESULTADOS E DISCUSSÃO:}

Os resultados foram obtidos por meio da observação participante e entrevistas. Inicialmente apresentaremos e discutiremos a observação de forma detalhada.

\subsection{Observação Participante}

Iniciamos a observação desde o primeiro contato com o grupo, começamos a verificar como eles agiam e interagiam, tanto no nível individual quanto coletivo.

Ao longo do processo, pudemos observar suas atitudes mais tênues, a maneira como chegavam, geralmente em pares, um grupo predominantemente feminino. Verificamos alguns casais entre o grupo. Alguns chegavam mais cedo e começavam a arrumação para as atividades, geralmente de cunho desportivo. Separavam o material, alguns improvisados e confeccionados por eles mesmos. Eles nos pareciam muito regrados e pontuais, quase não havendo atrasos nos encontros.

O monitor responsável por eles tinha muito carisma e era bem aceito pelo grupo. Conduzia com maestria, à medida que estabelecia controle das atividades, de uma maneira ativa e bem humorada, usando de forma clara e consciente, estratégias para mantê-los atentos e integrados ao processo. Utilizava sempre técnicas de motivação para conduzi-los, sabia os nomes de cada um. O repertório musical não variava muito, estava sempre entre o sertanejo e o pagode, as preferidas do grupo.

Com o passar do tempo e com a nossa freqüência nos encontros, eles já notavam nossa presença. Algumas vezes, nos perguntavam o que estávamos fazendo ali e qual era nossa pretensão. 
Durante essas observaçãoes, percebemos vários detalhes, como a interação de todos e a vibração dos integrantes durante as reuniões e durante as atividades, evidenciando o caráter coeso desse grupo.

A amizade que existia entre eles, o carinho mútuo, captado pelos nossos olhares durante as conversas. Percebíamos que se tratava de um ambiente saudável, que proporcionava uma grande e positiva vivência entre todos. Isto nos contagiou também.

Quando foram esclarecidos que iríamos pesquisá-los caso se sentissem interessados, a interação foi completa.

\subsection{Dados Sócio-Demográficos (Perfil)}

Traçamos os dados sócios demográficos do estudo. Verificamos que se trata de um grupo de idosos constituído por maioria de mulheres, com idades entre 60 e 82 anos, católicas (o), casadas (o), com filhos e netos. Apresentando-se com baixa escolaridade, maioria concluintes da $4^{\mathrm{a}}$ série do ensino fundamental, quase todos já aposentadas (os), tendo como renda variante, entre 1 (um) salário mínimo ( $\mathrm{R}$ \$ 350,00- trezentos e cinqüenta reais, no período vigente, ano 2006) e (R\$1970,00- mil novecentos e setenta reais). Com dedicação predominantemente, aos afazeres domésticos. Alguns ainda têm atividades lucrativas e mantêm-se no mercado de trabalho. Os dados aqui brevemente apresentados se dispõem nos quadros que se seguem. 
Quadro Aa-Dados de Identificação dos Idosos Pesquisados, segundo idade, sexo, religião, Estado Civil e Escolaridade.

\begin{tabular}{|c|c|c|c|c|c|}
\hline No & Idade & Sexo & Religião & Estado Civil & Escolaridade \\
\hline 01 & 79 & $\mathrm{~F}$ & Católica & Viúva & $1^{\circ}$ ano \\
\hline 02 & 74 & $\mathrm{M}$ & Só amo Deus & Viúvo & $1^{\circ}$ ano \\
\hline 03 & 68 & $\mathrm{~F}$ & Católica & Viúva & $1^{\circ}$ ano \\
\hline 04 & 63 & $\mathrm{~F}$ & Evangélica & Casada & $4^{\circ}$ ano \\
\hline 05 & 65 & $\mathrm{~F}$ & Católica & Casada & $4^{\circ}$ ano \\
\hline 06 & 70 & $\mathrm{~F}$ & Católica & Casada & Sup. Completo \\
\hline 07 & 68 & $\mathrm{~F}$ & Católica & Divorciada & $4^{\circ}$ ano \\
\hline 08 & 71 & $\mathrm{M}$ & Católico & Casado & $4^{\circ}$ ano \\
\hline 09 & 65 & $\mathrm{~F}$ & Católica & Casada & $4^{\circ}$ ano \\
\hline 10 & 65 & $\mathrm{~F}$ & Católica & Casada & $4^{\circ}$ ano \\
\hline 11 & 73 & $\mathrm{~F}$ & Católica & Viúva & $3^{\circ}$ ano \\
\hline 12 & 67 & $\mathrm{~F}$ & Católica & Casada & $3^{\circ}$ ano \\
\hline 13 & 68 & $\mathrm{M}$ & Católico & Casado & $4^{\circ}$ ano \\
\hline 14 & 65 & $\mathrm{~F}$ & Católica & Viúva & $4^{\circ}$ ano \\
\hline 15 & 63 & $\mathrm{~F}$ & Católica & Casada & $4^{\circ}$ ano \\
\hline 16 & 78 & $\mathrm{~F}$ & Budista & Viúva & --- \\
\hline 17 & 74 & $\mathrm{M}$ & Católico & Casado & Sup. Completo \\
\hline 18 & 62 & $\mathrm{M}$ & --- & Casado & Sup. completo \\
\hline 19 & 73 & $\mathrm{M}$ & Espirita & Casado & Sup. Completo \\
\hline 20 & 71 & $\mathrm{~F}$ & Católica & Casada & $5^{\circ}$ ano \\
\hline 21 & 67 & M & Católico & Casado & $\begin{array}{l}\text { Ens. } \\
\text { Fundamental }\end{array}$ \\
\hline 22 & 64 & $\mathrm{~F}$ & Católica & Casada & $1^{\circ}$ ano \\
\hline 23 & 66 & $\mathrm{~F}$ & Católica & Casada & $\begin{array}{l}\text { Ens. } \\
\text { Fundamental }\end{array}$ \\
\hline 24 & 70 & $\mathrm{~F}$ & Católica & Casada & $1^{\circ}$ ano \\
\hline 25 & 60 & $\mathrm{~F}$ & Católica & Viúva & $4^{\circ}$ ano \\
\hline 26 & 82 & $\mathrm{~F}$ & Católica & Viúva & $4^{\circ}$ ano \\
\hline
\end{tabular}

Quadro Ab-Dados de Identificação dos Idosos pesquisados, segundo profissão, renda mensal, filhos e netos.

\begin{tabular}{|c|c|c|c|c|c|c|}
\hline No. & Profissão & Renda Mensal & Tem Filhos & Quantos & Tem Netos & $\begin{array}{l}\text { Quanto } \\
\text { S }\end{array}$ \\
\hline 01 & Do lar & 1 Salário & Sim & 4 / 2 vivos & Sim & $\begin{array}{lr}9 & \text { netos } \\
\mathrm{e} & 5 \\
\text { bisnetos } \\
\end{array}$ \\
\hline 02 & Aposentado & 1 Salário & Não & --- & --- & --- \\
\hline 03 & Aposentada & $\mathrm{R} \$ 800,00$ & Sim & 4 & Sim & 8 \\
\hline 04 & Do lar & $\mathrm{R} \$ 300,00$ & Sim & 3 & Sim & 4 \\
\hline 05 & Do lar & --- & Sim & 3 & Sim & 8 \\
\hline 06 & Aposentada & $\mathrm{R} \$ 1.264,00$ & Sim & 4 & Sim & 4 \\
\hline 07 & Costureira & 1 Salário & Sim & 1 & Sim & 3 \\
\hline 08 & Aposentado & $<\mathrm{R} \$ 1.000,00$ & Sim & 4 & Sim & 7 \\
\hline 09 & Do lar & $\mathrm{R} \$ 700,00$ & Sim & 4 & Sim & 7 \\
\hline 10 & Do lar & $\begin{array}{ll}-- \\
\end{array}$ & Sim & 2 & Sim & 4 \\
\hline 11 & Do lar & $\mathrm{R} \$ 370,00$ & Sim & 4 & Sim & 9 \\
\hline 12 & --- & --- & Sim & 6 & Sim & 13 \\
\hline 13 & Aposentado & $\mathrm{R} \$ 1.970,00$ & Sim & 6 & Sim & 13 \\
\hline 14 & Aposentada & $\mathrm{R} \$ 500,00$ & Sim & 4 & Sim & 5 \\
\hline 15 & Aposentada & $\mathrm{R} \$ 1.500,00$ & Sim & 4 & Sim & 4 \\
\hline 16 & Do lar & $\mathrm{R} \$ 350,00$ & Sim & 7 & Sim & 16 \\
\hline 17 & Aposentado & $\mathrm{R} \$ 3.000,00$ & Sim & 4 & Sim & 4 \\
\hline 18 & $\begin{array}{l}\text { Funcionário } \\
\text { Público }\end{array}$ & --- & Sim & 1 & Não & --- \\
\hline 19 & Aposentado & $\mathrm{R} \$ 1.000,00$ & Sim & 2 & Sim & 5 \\
\hline 20 & Bordadeira & $\mathrm{R} \$ 1.300,00$ & Sim & 1 & Sim & 2 \\
\hline 21 & Aposentado & $\mathrm{R} \$ 1.000,00$ & Sim & 3 & Não & --- \\
\hline 22 & Aposentada & $\mathrm{R} \$ 449,00$ & Sim & 3 & Sim & 8 \\
\hline 23 & Do Lar & $\mathrm{R} \$ 350,00$ & Sim & 2 & Sim & 1 \\
\hline 24 & Do Lar & --- & Sim & 6 & Sim & 12 \\
\hline 25 & Pensionista & $\mathrm{R} \$ 800,00$ & Sim & 1 & Sim & 2 \\
\hline 26 & Aposentada & $\mathrm{R} \$ 1.200,00$ & Sim & 1 & Sim & 2 \\
\hline
\end{tabular}


6.3 Análise dos Resultados Referentes às Respostas das Questões Propriamente Ditas, do Estudo em Questão.

Quadro 1 - Representação qualitativa das respostas das falas dos idosos pesquisados sobre as questões: $O$ que é Lazer? $O$ que é Turismo?

\begin{tabular}{|c|c|c|}
\hline Sujeitos & O que é Lazer? & O que é Turismo? \\
\hline 01 & Fazer ginástica, caminhada ir à missa. & Viajar \\
\hline 02 & Tranqüilidade & Viaja ir pras viaje \\
\hline 03 & Viajar, dançar & Viaja \\
\hline 04 & Viajar, Clube & Viajar \\
\hline 05 & Fazer ginástica e caminhada & Passeio \\
\hline 06 & Tempo disponível, folga & Viajar \\
\hline 07 & Meu lar (onde eu moro) & Viajar \\
\hline 08 & Divertimento alegria prazer em viver & Viagens, estadual, nacional, etc \\
\hline 09 & Qualidade de vida & Passeio, viagem \\
\hline 10 & Distrair & Sair de casa \\
\hline 11 & Viajar, ir ao clube, ver amigos & Viajar, conhecer novos lugares \\
\hline 12 & Quando pode ir passear & Conhecer novos lugares \\
\hline 13 & Lazer é passear a vontade & Visitar novos lugares \\
\hline 14 & Descanso & Passear \\
\hline 15 & Passear, viajar, praticar atividade física & Viajar, conhecer novos lugares \\
\hline 16 & Diversão & Passear, conhecer gente nova \\
\hline 17 & Tempo disponível para divertir & Viajar em excursão feita por prazer \\
\hline 18 & Prática de atividades diferentes da rotina do dia a dia & Forma de conhecer novos lugares e culturas \\
\hline 19 & Divertimento, futebol e natação & Viagem \\
\hline 20 & Distração, vida & Conhecimento \\
\hline 21 & Passear, andar, Ter condição de viajar & Viajar \\
\hline 22 & PIC, viajar & Viajar \\
\hline 23 & Sair, passear, piscina, dançar & Viajar, praia \\
\hline 24 & Viver bem, passear & Viajar \\
\hline 25 & Passear, dançar & Viagem, passeio \\
\hline 26 & Coisa muito boa, música, viagem & Viajar \\
\hline
\end{tabular}

De acordo com as respostas apresentadas no Quadro 1 referente ao significado do lazer e turismo essas nos permitiram chegar às seguintes categorizações.

\section{CATEGORIZAÇÃO DO SIGNIFICADO DO LAZER:}

- Relativo aos aspectos sócio-culturais:

Lazer é: “viajar”, “passeio”, “divertimento”, “distração”, “tempo”, “disponível para divertir”, “dançar”, “meu lar”, “onde moro”, “ver amigos”, “passear à vontade”, “ter condição de viajar", "sair”, "PIC”, "música” (S:03,04,06,07,08,10,11,12,13,15,16,19,20,21,22,23,24,25 e 26).

- Relativo aos aspectos desportivos:

Lazer é: “Caminhar e andar”, “ir ao clube”, “fazer ginástica”, "praticar atividade física”, “futebol”, “piscina” (S:01,04,05,11,15 e 19). 


\section{- Relativo ao bem estar:}

Lazer é: “Tranqüilidade”, “alegria de viver”, “qualidade de vida”, “prática de atividades diferentes da rotina do dia a dia”, “vida, viver bem”, “uma coisa muito boa” (S:02,08,09,18,24 e 26).

- Relativo ao descanso:

Lazer é: “Descanso”, “folga” (S:14 e 17).

- Relativo aos aspectos religiosos:

Lazer é: “Missa” (S:01).

Grande parte dos idosos entrevistados dá significado ao lazer, relacionando-o ao aspecto sócio-cultural da atividade, sendo as mesmas de grande importância para a inserção e/ou a manutenção da vida social do idoso, impedindo dessa maneira, que ao se interagir, o mesmo não caia no isolamento social, favorecendo assim, a sua saúde mental. Além disto, o meio onde o idoso está inserido, seja em seu lar e ou em um grupo, difere a percepção do tempo e conseqüentemente, a valorização do mesmo. Isso vem interferir na maneira de “gastar” o seu tempo, atribuindo valor às atividades realizadas (BACAL, 2003).

Por vezes as respostas da evidência do lazer relacionadas aos aspectos desportivos atividades desportivas são amplamente mostradas no PIC, e são, segundo eles consideradas também benéficas para os seres humanos, ou seja, ligadas ao bem-estar em todas as fases da vida, sobretudo para os idosos, que encontram nas atividades, um momento de relaxamento e sociabilidade, além de estarem contribuindo conscientemente, para promoção de sua saúde física e conseqüentemente de sua saúde mental.

É de extrema importância o significado do lazer relacionado ao descanso, pois para que haja lazer, é preciso haver trabalho e/ou obrigações, seja de qualquer natureza, não podendo o lazer, ser confundido com o ócio ou preguiça, pois esse é a própria negação do 
trabalho e ou obrigações de outras naturezas (MARCELLINO, 2000). Deveras o descanso é preconizado como umas das funções do lazer, e está diretamente ligada a idéia de refazimento físico, contribuindo para o bem estar do indivíduo idoso (DUMAZEDIER, 2000).

Muitos idosos atribuíram o significado de lazer a atitudes, sentimentos e à prática de ordem positiva. Em termos do bem estar dos indivíduos em geral, e/ou dos idosos, vale ressaltar que esse sentimento obtido através do lazer, se traduz na realidade da saúde física e mental das pessoas (ANDRADE, 2001).

Os aspectos religiosos estão muito presentes na vida dos idosos, sendo aqui apontado até mesmo como lazer, desde que essas atividades não sejam entendidas como obrigações, ela deve sim configurar como uma opção de lazer para o idoso.

Ainda, vale salientar que o aspecto espiritual, a crença religiosa, freqüentemente é de grande importância na vida do idoso, pois pode ajudar tanto nos momentos difíceis e em situações dolorosas quanto em momentos de alegria (RODRIGUES; DIOGO; BARROS, 2004).

Sendo assim, acreditamos que seja importante para os idosos participarem de atividades de cunho religioso.

\section{CATEGORIZAÇÃO DO SIGNIFICADO DO TURISMO:}

- Relativo Aos Aspectos Sócio-Culturais:

Turismo é: “viajar”, “passeio”, "sair de casa”, “conhecer gente nova”, “conhecimento”, “praia”(S:01,02,03,04,05,06,07,08,09,10,11,12,13,14,15,16,17,18,19,20,21,22,23, 24,25 e 26).

A grande maioria dos idosos relacionou a atividade turística aos aspectos sócioculturais, atribuindo o real significado do turismo, ligado ao deslocamento (viagens) e às novas experiências, quando mencionam viagem, sair de casa, ir à praia, etc. Então o turismo é 
entendido como a quebra do cotidiano, que permite ao indivíduo, restabelecer o seu equilíbrio interno, à medida que representa uma fuga temporária do ambiente constrangedor (BACAL, 2003).

Assim, as atividades de turismo e/ou ligadas às férias, são, talvez, as mais importantes formas de diversão, descontração e entretenimento, dentre as atividades de lazer propriamente dito, devido à sua duração e a sedução que exercem (DUMAZEDIER, 2000). Desta forma, acreditamos que o turismo vai além do deslocamento físico. É uma decisão psicológica, pois permite aos indivíduos, inclusive aos idosos, ter contato com o novo, à busca de satisfação, sendo então, traduzida em bem-estar (BUENO, 1981).

Quadro 2 - Representação qualitativa das respostas das falas dos idosos pesquisados sobre as questões: Você se distrai? Sim ( )Não ( ) Como?

\begin{tabular}{|l|l|l|l|}
\hline Sujeitos & Sim & Não & Como? \\
\hline 01 & X & & Com tudo que tem na igreja \\
\hline 02 & X & & Ir pro clube \\
\hline 03 & X & & Baile \\
\hline 04 & X & & Viajando \\
\hline 05 & X & & Fazendo ginástica vendo TV \\
\hline 06 & X & & Tendo uma boa conversa, cinema \\
\hline 07 & X & & Costurando \\
\hline 08 & X & & Ouvindo música, etc \\
\hline 09 & X & & --- \\
\hline 10 & X & & Saindo de casa \\
\hline 11 & X & & Passeio com o PIC \\
\hline 12 & X & & Passeando \\
\hline 13 & X & & Passeando \\
\hline 14 & X & & PIC \\
\hline 15 & X & & Converso com todo mundo \\
\hline 16 & X & & Faço ginástica e cuido da horta \\
\hline 17 & X & & Com amigos \\
\hline 18 & X & & Leitura, trabalho, música, etc. \\
\hline 19 & X & & PIC, rancho, pesca \\
\hline 20 & X & & Ginástica, pescaria e caminhada \\
\hline 21 & X & & PIC \\
\hline 22 & X & & PIC e viagem, é muito bom \\
\hline 23 & X & & Dançando, conversando e viajando \\
\hline 24 & X & & Saindo, andando, ficar fora de casa \\
\hline 25 & X & & Conversando e rindo bastante \\
\hline 26 & & & Dançando, conversando, quadrilha. \\
\hline
\end{tabular}

\section{CATEGORIZAÇÃO DA PRÁTICA DO LAZER COMO DISTRAÇÃO:}

Conforme o Quadro 2 , relativo a questão- se distraem e como, as respostas emitidas pelos idosos pesquisados, nos permitiram chegar as seguintes categorizações. 


\section{- Relativo aos aspectos sócio-culturais:}

Como se divertem: “Conversando”, “tendo uma boa conversa”, “PIC”, “passeando”, “viajando”, “dançando”, “ouvindo música”, “saindo”, “ficar fora de casa”, “baile”, “ver TV", "cinema"," com amigos", "dançar quadrilha". (S:03,04,05,06,08,10,11,12,13,14,15,17,18,19,21,22,23,24,25 e 26).

- Relativo aos aspectos desportivos:

Como se divertem: “Fazendo ginástica”, “pescaria”, “andando”, “caminhando”, “ficando fora de casa”, "rancho”, "ir pro clube” (S:02,05,16,19,20 e 24).

- Relativo à semilazer:

Como se divertem: “Costurando”, “cuidando da horta”, “trabalho” (S: 07,16 e 18).

- Relativo aos aspectos religiosos:

Como se divertem: “com tudo que tem na igreja” (s:01).

- Relativo aos aspectos intelectuais:

Como se divertem: “Leitura” (S:18).

- Relativo a outros aspectos:

Como se divertem: “Rindo bastante” (S:25).

Todos os idosos se distraem, seja por meio de circunstâncias sócio-culturais, desportivas, praticando semilazer, atividades religiosas, intelectuais, entre outras, indo ao encontro com a segunda função do lazer que visa o divertimento, recreação e entretenimento, que engloba quase todas as formas de distração. Conforme aqui mencionadas, por exemplo, se distrai: conversando, passeando, viajando, dançando, assistindo TV e cinema, fazendo ginástica, pescando, andando, indo ao clube, costurando, trabalhando, cuidando da horta, indo à igreja, fazendo leitura, rindo, etc. (DUMAZEDIER, 2000).

Todavia vale destacar que atividades de cunho obrigatório não podem ser consideradas 
como lazer, fugindo do real significado, pois que o mesmo demanda sentido de liberdade, de descomprometimento, ser lícito, voluntariamente, com a função de diversão e distração.

Desde que essas atividades englobem apenas interesses práticos, de realização pessoal e passatempo, elas podem ser consideradas lazer. Essas atividades podem ser exemplificadas com as respostas emitidas pelos sujeitos acima, quanto à questão do trabalho. Só pode ser considerado então semilazer, o trabalho que não é realizado obrigatoriamente.

Exemplificamos na questão do futebol, uma prática que pode ser profissional não lazer. Mas se houver uma jogada amistosa, sem fins lucrativos, é lazer. Um músico, um artesão, que exercem seu trabalho por prazer e sem obrigatoriedade, é uma atividade considerada semilazer (CAMARGO, 1999).

Quanto à questão dos aspectos intelectuais, evidenciamos então, a adequação à terceira função do lazer, a função de desenvolvimento pessoal (BUENO, 1981; DUMAZEDIER, 2000). Para que o lazer assuma essa função, é necessário considerar suas potencialidades para o desenvolvimento pessoal, auxiliando na formação sócio-cultural do indivíduo, nesse caso, os idosos, que por meio dessas atividades, podem trabalhar a sua cognição, estimulando-a. 
Quadro 3 - Representação qualitativa das respostas das falas dos idosos sobre as questões: $O$ que você mais gosta de fazer? $O$ que você menos gosta de fazer?

\begin{tabular}{|l|l|l|}
\hline Sujeitos & O que você mais gosta de fazer? & O que você menos gosta de fazer? \\
\hline 01 & Ginástica ir na missa & Passar roupa \\
\hline 02 & Viver em paz com Deus & Pagar os outros \\
\hline 03 & Passear & Trabalhar \\
\hline 04 & Ajudar as pessoas & Passar roupas \\
\hline 05 & Assistir novela & Não cozinhar \\
\hline 06 & Passear & Ficar sem fazer nada \\
\hline 07 & Passear & Passar roupa \\
\hline 08 & Tudo que me dá prazer, sexo & Ter inimizade \\
\hline 09 & Cuidar de crianças e dar atenção & ---- \\
\hline 10 & Sair e viajar & Ficar parado \\
\hline 11 & Ir ao PIC, ir à Igreja, ver amigos & Ficar sozinha \\
\hline 12 & Passear & Fofoca \\
\hline 13 & Arrumar boas amizades & Fazer fofoca \\
\hline 14 & Viajar & --- \\
\hline 15 & Fazer & Ficar falando mal de outros \\
\hline 16 & comida, bolo, trabalhar na loja & \\
\hline 17 & Pintar e fazer tricô & Ficar parado \\
\hline 18 & Reunir com os amigos & Usar computador \\
\hline 19 & Ler, viajar, conviver com a família & Ir a lugares muito movimentados \\
\hline 20 & Passear, caminhar & Jogar bola \\
\hline 21 & Baile & Ficar sozinha \\
\hline 22 & Conversar, fazer novas amizades & Ficar em casa sem atividades \\
\hline 23 & Ir na missa & Passar roupa \\
\hline 24 & Dançar & Fazer comida \\
\hline 25 & Passear, dançar, TV, família & Não tem o que não gosto \\
\hline 26 & Passear, dançar, PIC & Gosto de tudo \\
\hline & Rezar, missa, PIC, ginástica & Tomar conta de casa: criança, cachorro \\
\hline
\end{tabular}

\section{CATEGORIZAÇÃO DO QUE OS IDOSOS PESQUISADOS MAIS GOSTAM DE FAZER:}

Em relação ao que mais gostam de fazer, apresentaram atividades ligadas aos aspectos sócio-culturais, religiosos, desportivos, semilazer e intelectuais, entre outros, conforme as categorizações que se seguem:

\section{- Relativo aos aspectos sócio-culturais:}

O que mais gosto de fazer é: “Passear”, “ver amigos”, “arrumar boas amizades”, “fazer novas amizades”, “reunir com os amigos”, “viajar”, “dançar”, “PIC”, “família”, “conviver com a família”, “ajudar as pessoas”, “assistir novela”, “sair”, “TV”, “baile”, “conversar”. (S:03,04,05,06,07,10,11,12,13,14,17,18,19,20,21,23,24,25 e 26).

- Relativo aos aspectos religiosos:

O que mais gosto de fazer é: “Rezar”, “ir à missa”, “ir à igreja”, “viver em paz com Deus”. (S:01,02,11,22 e 26). 
- Relativo aos aspectos desportivos:

O que mais gosto de fazer é: “Ginástica”, “caminhar”. (S:01,19 e 26).

- Relativo ao semilazer:

O que mais gosto de fazer é: “Fazer comida”, “bolo e trabalhar na loja”, “cuidar de crianças”, “dar atenção” "Pintar e fazer tricô”. (S:09, 15 e 16).

- Relativo aos aspectos intelectuais:

O que mais gosto de fazer é: “Ler”. (S:18).

- Relativo a outros aspectos:

O que mais gosto de fazer é: “Tudo que me dá prazer”, “sexo”. (S:08).

Tanto os aspectos sócio- culturais, desportivos e religiosos, são atividades centradas em interesses culturais e físicos, bem como são atividades gratuitas, prazerosas, voltadas à busca de compensar e ou substituir algum esforço que a vida social lhes impõe (CAMARGO, 1999).

Além do que a realização das mesmas promove um entorno saudável, ideal para a vida dos idosos, o que se confirma ao afirmarem que as coisas que mais gostam de fazer estão atreladas a esses aspectos (BACAL, 2003).

Muitos idosos têm atividades relativas à vida cotidiana, porém muitos deles não às vêem como uma obrigação. Por isso classificamos essas atividades como semilazer, ao passo que mesmo realizando-as, elas não são encaradas como obrigação, e, além disso, lhes dão prazer, fato observado no instante em que responderam que são as atividades que mais gostam de fazer (CAMARGO, 1999).

O aspecto intelectual nos faz crer que os idosos não devem ser considerados incapazes intelectualmente, pelo contrário, acumularam muito conhecimento ao longo de sua vida, alguns continuam a se preocupar com esse aspecto, encontrando prazer nessas atividades.

O idoso descreve acima a preocupação com o prazer e o sexo, evidenciando que a vida 
sexual do indivíduo não termina na velhice, o idoso também gosta e se preocupa com o sexo.

Muitos acreditam que a relação sexual tem sido considerada uma atividade própria das pessoas jovens e fisicamente atraentes. A idéia de que as pessoas idosas também possam manter relações sexuais não é culturalmente muito aceita. Apesar disso, os idosos conservam a necessidade psicológica de uma atividade sexual continuada não havendo idade em que a atividade sexual, os pensamentos sobre sexo ou o desejo acabem (BALLONE, 2004).

\section{CATEGORIZAÇÃO DAS ATIVIDADES QUE OS IDOSOS MENOS GOSTAM DE FAZER:}

Em relação ao que menos gostam de fazer, apresentaram atividades ligadas aos aspectos ocupacionais, de ociosidade, solidão, entre outros, conforme as categorias que se seguem.

\section{- Relativo aos aspectos ocupacionais:}

O que menos gosto de fazer é: “Passar roupa”, "trabalhar”, “fazer comida”,"usar computador”, “tomar conta de casa, criança e do cachorro”. (S:01,03,04,07,17,22,23 e 26).

- Relativo aos aspectos de ociosidade:

O que menos gosto de fazer é: "Ficar muito parado", "ficar em casa sem atividades", "ficar sem fazer nada”. (S:06,10,16 e 21).

- Relativo aos aspectos de solidão:

O que menos gosto de fazer é: “ficar sozinha”. (S:11 e 20).

- Relativo à não ter o que não gosta:

O que menos gosto de fazer é: “Não tem do que não gosto”, “gosto de tudo”. (S:24 e 25).

- Relativo a outros:

O que menos gosto de fazer é: “Pagar os outros”, “não cozinhar”, “ter inimizade”, “ir a lugares muito movimentados”, “jogar bola”. (S:02,05,08,18 e 19 ). 
Os idosos entrevistados relataram que não gostam das atividades ocupacionais, pois acreditamos que muitas vezes, levam ao tédio e a rotina, quando isso acontece essas atividades perdem o seu interesse.

Quanto às atividades ligadas à ociosidade e a solidão, encontramos umas situações parecidas, no que se refere à questão de interesse. Esses aspectos estão ligados também ao tédio, à falta de prazer, estimulando os idosos a perderem contato social e conseqüentemente, apresentarem uma vida sem anseios e sem alegria. Caso essa situação perdure, pode vir a comprometer a saúde mental do idoso (BALLONE, 2004).

As atividades associativas de lazer, que contém um forte conteúdo de sociabilidade, expresso no contato com os amigos, parentes e colegas de bairro, assim como, as atividades de grupo, pode contribuir para a ausência dessa solidão (CAMARGO, 1999).

Os idosos que responderam que não existe nada que não gostam, parece- nos evidenciar uma postura positiva e feliz no enfrentamento do cotidiano, demonstram que estão completos e realizados, à medida que nada, no momento, os incomodam.

Quadro 4 - Representação qualitativa das respostas das falas dos idosos pesquisados sobre a questão: Quando você se distrai com o que você gosta, como se sente?

\begin{tabular}{|l|l|}
\hline Sujeitos & Quando você se distrai com o que você gosta, como se sente? \\
\hline 01 & Muito bem \\
\hline 02 & Feliz \\
\hline 03 & Bem \\
\hline 04 & Bem \\
\hline 05 & Feliz \\
\hline 06 & Muito bem \\
\hline 07 & Me sinto bem \\
\hline 08 & Feliz \\
\hline 09 & Feliz \\
\hline 10 & Boa \\
\hline 11 & Bem, feliz \\
\hline 12 & --- \\
\hline 13 & Bem \\
\hline 14 & --- \\
\hline 15 & Alegre, feliz \\
\hline 16 & Se sente bem \\
\hline 17 & Muito bem \\
\hline 18 & Bem \\
\hline 19 & Muito bem \\
\hline 20 & Corpo alegre, alma alegre \\
\hline 21 & Muito bem \\
\hline 22 & Muito bem, o nervoso vai embora \\
\hline 23 & Bem \\
\hline 24 & Bem \\
\hline 25 & Bem, realizada e feliz \\
\hline 26 & Bem, ótima, pareço mais jovem \\
\hline
\end{tabular}


CATEGORIZAÇÃO QUANDO VOCÊ SE DISTRAI COM O QUE VOCÊ GOSTA, COMO SE SENTE:

Conforme o Quadro 4 as respostas permitiram chegar às seguintes categorias, relacionando ao bem-estar, felicidade, alegria, entre outros.

- Sentimento relacionado ao bem-estar:

Sinto-me: “bem”, “muito”, “bem”, “ótima”, “realizada” (S: 01,03,04,06,07,10, $11,13,16,17,18,19,21,22,23,24,25$ e 26$).$

- Sentimento relacionado à felicidade:

Sinto-me: “Feliz” (S:02,05,08,09,11,15 e 25).

- Sentimento relacionado à alegria:

Sinto-me: “alegre” “alma alegre e corpo alegre” (S:15 e 20).

- Sentimento relacionado a outros:

Sinto-me: “O nervoso vai embora, pareço mais jovem” (S: 22 e 26).

Á partir das respostas obtidas, evidenciamos, a relação da realização de atividades que dão prazer, aos sentimentos de bem-estar e alegria. Esses sentimentos positivos que nos faz suscitar, um bom cotidiano e uma vida saudável. A distração está ligada à descontração e à felicidade (BUENO, 1981).

O lazer, englobando a distração, parte do princípio da busca pelo prazer, ele também é sempre liberatório de obrigações, os idosos têm nesse tempo de distração a oportunidade de recuperação psicossocial e de desenvolvimento pessoal (REQUIXA, 1980).

Portanto os idosos ao se distraírem, optam por atividades de livre escolha, de forma voluntária, em seu tempo disponível, que por sua vez vêm proporcionar efeitos positivos, como descanso físico e mental, bem como desenvolvimento da personalidade e da sociabilidade (MARCELLINO, 1990). Constituindo assim, um mecanismo positivo na busca de seu bem-estar. 
Quadro 5- Representação qualitativa das respostas das falas dos idosos pesquisados sobre a questão: Quando se faz lazer e viaja, como fica a cabeça?

\begin{tabular}{|l|l|}
\hline Sujeitos & Quando se faz lazer e viaja, como fica a cabeça? \\
\hline 01 & Contente e feliz \\
\hline 02 & Tranqüilidade \\
\hline 03 & Bem \\
\hline 04 & Bem \\
\hline 05 & Tranqüila, alegre e feliz \\
\hline 06 & Ótima \\
\hline 07 & Ótima \\
\hline 08 & Esqueço de tudo \\
\hline 09 & Preocupada \\
\hline 10 & Boa \\
\hline 11 & Arejada \\
\hline 12 & Alegre \\
\hline 13 & Normal \\
\hline 14 & Tranqüila \\
\hline 15 & Eu me sinto feliz \\
\hline 16 & Leve \\
\hline 17 & Muito bem \\
\hline 18 & Leve \\
\hline 19 & Muito bem \\
\hline 20 & Mais leve \\
\hline 21 & Muito bem \\
\hline 22 & Muito boa, ás vezes penso em não ir, mas depois fica muito boa \\
\hline 23 & Boa \\
\hline 24 & Boa, muito boa \\
\hline 25 & Boa, ótima \\
\hline 26 & Ótima, boa, ficar dentro de casa me deixa doente \\
\hline & \\
\hline
\end{tabular}

\section{CATEGORIZAÇÃO QUANDO FAZ LAZER E VIAJA, COMO FICA A CABEÇA:}

De acordo com os resultados do Quadro 5 (Item B), relativo a questão: Quando se faz lazer e viaja, como fica a cabeça?

- Sentimento relacionado ao bem-estar:

Fica: “Boa”, “muito boa”, “ótima”, “muito bem”. (S:10,17,19,21,22,23,24,25 e 26).

- Sentimento relacionado à tranqüilidade:

Fica: “Leve”, “arejada”, “mais leve”, “tranqüila”, “tranqüilidade”, (S:02,05,11,14,16,18 e 20 ).

- Sentimento relacionado à felicidade:

Fica: “Feliz” (s:01,05 e 15).

- Sentimento relacionado à alegria:

Fica: “Alegre”, “contente”. (S:01,05 e 12).

\section{- Sentimento relacionado a outros:}

Fica: "Ficar dentro de casa me deixa doente”, “normal”, “esqueço de tudo”, "preocupada”, “às vezes penso em nem ir, mas depois a cabeça fica muito boa” (S:08,09,13,22 e 26). 
O turismo é visto como uma das mais nobres opções de lazer. Está ligada a mudança de paisagem, a quebra do estilo de vida. Conhecer novos lugares e alterar o nosso cotidiano momentaneamente são experiências que o turismo nos oferece (CAMARGO, 1999).

Viajamos motivados por diversos fatores, contemplação, saúde, finalidades artísticas, culturais, entre outros. Mas sempre em busca de felicidade e diversão (TRIGO, 1998).

As atividades de lazer e turismo proporcionam prazer e são alternativas na vida dos idosos. Isso faz com que os sentimentos que emergem após essa experiência, reflitam na vida do idoso, não somente durante o deslocamento, mas também depois de seu retorno, favorecendo a sua auto-estima (FROMER, VIEIRA, 2003).

Podemos observar essa afirmação à medida que analisamos as respostas emitidas pelos idosos questionados. As categorias revelam satisfação, felicidade e bem-estar, evidenciando quanto se sentem realizados por isso.

Evidentemente deve ser respeitada durante essas atividades a capacidade física de cada um, para que seja considerada gratificante.

Quadro 6 - Representação qualitativa das respostas das falas dos idosos pesquisados sobre as questões: Você tem viajado? Com quem? ( ) Família ( ) Amigos ( ) Outros

\begin{tabular}{|c|c|c|c|c|c|}
\hline Sujeitos & Sim & Não & Família & Amigos & Outros \\
\hline 01 & $\mathrm{X}$ & & $\mathrm{X}$ & $\mathrm{X}$ & \\
\hline 02 & $\mathrm{X}$ & & & & $\mathrm{X}$ \\
\hline 03 & $\mathrm{X}$ & & & $\mathrm{X}$ & \\
\hline 04 & $\mathrm{X}$ & & & $\mathrm{X}$ & \\
\hline 05 & $\mathrm{X}$ & & & $\mathrm{X}$ & \\
\hline 06 & $\mathrm{X}$ & & $\mathrm{X}$ & & \\
\hline 07 & $\mathrm{X}$ & & & $\mathrm{X}$ & \\
\hline 08 & $\mathrm{X}$ & & --- & --- & --- \\
\hline 09 & $\mathrm{X}$ & & & $\mathrm{X}$ & \\
\hline 10 & $\mathrm{X}$ & & $\mathrm{X}$ & & \\
\hline 11 & $\mathrm{X}$ & & $\mathrm{X}$ & & \\
\hline 12 & $\mathrm{X}$ & & --- & --- & --- \\
\hline 13 & $X$ & & --- & --- & --- \\
\hline 14 & $\mathrm{X}$ & & & $\mathrm{X}$ & \\
\hline 15 & $\mathrm{X}$ & & $\mathrm{X}$ & & \\
\hline 16 & $\mathrm{X}$ & & & $\mathrm{X}$ & \\
\hline 17 & $\mathrm{X}$ & & $\mathrm{X}$ & & \\
\hline 18 & $\mathrm{X}$ & & $\mathrm{X}$ & $\mathrm{X}$ & \\
\hline 19 & & $\mathrm{X}$ & & & \\
\hline 20 & $\mathrm{X}$ & & $\mathrm{X}$ & & \\
\hline 21 & $\mathrm{X}$ & & $\mathrm{X}$ & & \\
\hline 22 & $\mathrm{X}$ & & & $\mathrm{X}$ & \\
\hline 23 & & $\mathrm{X}$ & & & \\
\hline 24 & $\mathrm{X}$ & & $\mathrm{X}$ & & \\
\hline 25 & $\mathrm{X}$ & & $\mathrm{X}$ & & \\
\hline 26 & $\mathrm{X}$ & & & $\mathrm{X}$ & \\
\hline
\end{tabular}


CATEGORIZAÇÃO SE TEM VIAJADO:

- Indicador positivo de viagem:

Respostas: (S:01,02,03,04,05,06,07,08,09,10,11,12,13,14,15,16,17,18,20,21,22,24,25 e 26).

- Viajam com amigos:

Respostas: (S:01,03,04,05,07,09,14,16,18,22 e 26).

- Viajam com a família:

Respostas: (S:01,06,10,11,15,17,18,20,21,24 e 25).

- Outros: (S:02).

A maioria dos idosos relata que viaja, dentre eles o número dos que viajam com a família se iguala ao número dos que viajam com os amigos.

Quadro 7 - Representação qualitativa das respostas das falas dos idosos pesquisados sobre as questões: Você viaja com que frequência? （） Muito （） Pouco.

\begin{tabular}{|l|l|l|}
\hline Sujeitos & Muito & Pouco \\
\hline 01 & X & \\
\hline 02 & & X \\
\hline 03 & & X \\
\hline 04 & & X \\
\hline 05 & & X \\
\hline 06 & X & X \\
\hline 07 & & \\
\hline 08 & & X \\
\hline 09 & & X \\
\hline 10 & & X \\
\hline 11 & --- & X \\
\hline 12 & --- & --- \\
\hline 13 & & --- \\
\hline 14 & $X$ & $X$ \\
\hline 15 & & \\
\hline 16 & & $X$ \\
\hline 17 & & $X$ \\
\hline 18 & & $X$ \\
\hline 19 & & $X$ \\
\hline 20 & & $X$ \\
\hline 21 & & $X$ \\
\hline 22 & & $X$ \\
\hline 23 & X & X \\
\hline 24 & & X \\
\hline 25 & X & \\
\hline 26 & & \\
\hline & & \\
\hline
\end{tabular}




\section{CATEGORIZAÇÃO SE VIAJA COM QUE FREQÜÊNCIA:}

- Relativo a pouca oportunidade de viagem:

Respostas: (S:02,03,04,05,06,08,09,11,14,16,17,18,19,20,21,22,23 e 25).

- Relativo à intensidade:

Respostas: (S:01,07,15,24e26).

Percebemos que grande parte dos idosos, apesar de relatar que viajam e que têm interesse em viajar, não possui muita oportunidade para tal. Acreditamos que isso se deve ao fato de muitos idosos, não serem bem remunerados por suas aposentadorias, trabalho e ou pensões. Ou mesmo por falta de estímulo e vontade, já que muitos não encontram produtos que os satisfaçam no mercado turístico.

Existe a crença que o idoso, só viaja em grupos e que não adere a uma série de atrações, porém, isso nem sempre ocorre. Acreditamos ser necessário a adequação de serviços turísticos elaborados e exeqüíveis para essa demanda que cresce a cada ano no mundo (FROMER, VIEIRA, 2003). Levando sempre em consideração suas aspirações, desejos, fantasias e limitações. 
Quadro 8 - Representação qualitativa das respostas das falas dos idosos pesquisados sobre as questões: Esse ano já viajou? E para o próximo ano pensa em viajar?

\begin{tabular}{|c|c|c|c|c|}
\hline \multirow{2}{*}{ Sujeitos } & \multicolumn{2}{|c|}{ Esse ano já viajou? } & \multicolumn{2}{|c|}{ E para o próximo ano pensa em viajar? } \\
\hline & Sim & Não & Sim & Não \\
\hline 01 & $\mathrm{X}$ & & $\mathrm{X}$ & \\
\hline 02 & & $\mathrm{X}$ & $\mathrm{X}$ & \\
\hline 03 & & $\mathrm{X}$ & $X$ & \\
\hline 04 & --- & --- & --- & --- \\
\hline 05 & $\mathrm{X}$ & & $\mathrm{X}$ & \\
\hline 06 & $\mathrm{X}$ & & $\mathrm{X}$ & \\
\hline 07 & $\mathrm{X}$ & & $\mathrm{X}$ & \\
\hline 08 & $\mathrm{X}$ & & $\mathrm{X}$ & \\
\hline 09 & $\mathrm{X}$ & & $\mathrm{X}$ & \\
\hline 10 & $\mathrm{X}$ & & $\mathrm{X}$ & \\
\hline 11 & $\mathrm{X}$ & & $\mathrm{X}$ & \\
\hline 12 & $\mathrm{X}$ & & $\mathrm{X}$ & \\
\hline 13 & $\mathrm{X}$ & & --- & --- \\
\hline 14 & $\mathrm{X}$ & & $\mathrm{X}$ & \\
\hline 15 & $\mathrm{X}$ & & $\mathrm{X}$ & \\
\hline 16 & $\mathrm{X}$ & & $\mathrm{X}$ & \\
\hline 17 & $\mathrm{X}$ & & $\mathrm{X}$ & \\
\hline 18 & $\mathrm{X}$ & & $\mathrm{X}$ & \\
\hline 19 & & $\mathrm{X}$ & $\mathrm{X}$ & \\
\hline 20 & $\mathrm{X}$ & & & $\mathrm{X}$ \\
\hline 21 & $\mathrm{X}$ & & $\mathrm{X}$ & \\
\hline 22 & & $\mathrm{X}$ & & $\mathrm{X}$ \\
\hline 23 & & $\mathrm{X}$ & $\mathrm{X}$ & \\
\hline 24 & $\mathrm{X}$ & & & $\mathrm{X}$ \\
\hline 25 & $\mathrm{X}$ & & $\mathrm{X}$ & \\
\hline 26 & $X$ & & $\mathrm{X}$ & \\
\hline
\end{tabular}

\section{CATEGORIZAÇÃO SE ESSE ANO JÁ VIAJOU:}

- Relativo a indicador positivo:

Respostas: (S:01,05,06,07,08,09,10,11,12,13,14,15,16,17,18,20,21,24,25 e 26).

- Relativo a indicador negativo:

Respostas: (S:02,03,19,22 e 23).

\section{CATEGORIZAÇÃO SE DESEJA VIAJAR NO PRÓXIMO ANO}

- Relativo a indicador positivo:

Respostas: (S:01,02,03,05,06,07,08,09,10,11,12,14,15,16,17,18,19,21,23,25 e 26).

- Relativo a indicador negativo:

Respostas: (S:20,22 e 24). 
Podemos perceber que grande parte dos idosos entrevistados viajou nesse período, ressaltando a adesão ao turismo, é relevante que existam políticas e um mercado turístico preocupado com os idosos, de forma que estejam preparados e aptos para trabalhar com as suas especificidades (FROMER; VIEIRA, 2003).

Em contrapartida encontramos sujeitos que não viajaram esse ano, esse indicador negativo pode provir de várias esferas, desde questões relativas à sua saúde quanto às questões financeiras, mas é evidente nos resultados encontrados que mesmos os sujeitos que não viajaram, demonstram desejo em realizar viagens turísticas para o próximo ano, evidenciando o grande interesse dos idosos.

O turismo como forma de lazer, é uma necessidade e um direito tão legítimo do ser humano, quanto educação, saúde ou segurança. O ser humano, idoso ou não, necessita mais do que o indispensável à sua sobrevivência. Sua vida envolve aspectos mais amplos, como os lúdicos, imaginativos e criativos que se manifestam por meio do lazer e do turismo (TRIGO, 1998)

Políticas de incentivo ao turismo para o idoso começam a surgir, através de leis e iniciativas públicas que procuram fomentar o acesso e a facilidade para o idoso adquirir os serviços desse setor, podemos citar como exemplo o Viaja Mais Melhor Idade, do Ministério do Turismo. Porém esses programas estão ainda em fase de implantação e sem resultados concretos até o presente momento.

Acreditamos que o idoso ao realizar, ou aspirar pelo turismo, anseia o descobrimento e ou preenchimento do seu "eu", por vezes encontrando um novo significado à sua vida, convertendo-o em aumento de sua auto-estima, promovendo sua saúde mental. 
Quadro 9 - Representação qualitativa das respostas das falas dos idosos pesquisados sobre a questão: $O$ que significa amizade para você?

\begin{tabular}{|c|c|}
\hline Sujeitos & O que significa amizade para você? \\
\hline 01 & Uma coisa maravilhos, uma maravilha \\
\hline 02 & Viver em paz sem brigar com ninguém \\
\hline 03 & Muito bom \\
\hline 04 & Importante \\
\hline 05 & Lealdade, respeito \\
\hline 06 & Sentimento fiel de afeição \\
\hline 07 & Amizade é tudo \\
\hline 08 & Tudo de bom na vida \\
\hline 09 & Muito boa \\
\hline 10 & Ter amigos em quem confiar \\
\hline 11 & Hoje uma conquista \\
\hline 12 & Muita alegria \\
\hline 13 & Quando é amizade, é bom \\
\hline 14 & Tudo \\
\hline 15 & Amizade é a melhor coisa \\
\hline 16 & Ter amigos \\
\hline 17 & Muito prazer \\
\hline 18 & Poder confiar em outras pessoas \\
\hline 19 & Tudo, Ter alegria, bater papo \\
\hline 20 & Tudo na vida, é o principal \\
\hline 21 & Honestidade \\
\hline 22 & È muito bom ter amigos \\
\hline 23 & Uma coisa importante, distrai \\
\hline 24 & A coisa mais importante \\
\hline 25 & Muito bom, adoro ter amizade \\
\hline 26 & Uma coisa muito gostosa \\
\hline
\end{tabular}

\section{SIGNIFICADO DA AMIZADE:}

\section{- Relacionado a algo bom/maravilhoso:}

Amizade é: “Uma coisa maravilhosa, uma maravilha”, "o tudo”, "o tudo na vida”, "tudo de bom na vida”, “muito bom”, “amizade é a melhor coisa”, “muito boa”, “tudo, ter alegria”, “tudo na vida, é o principal”, “uma coisa muito gostosa”. (S:01,03,07,08,09,14,15,19,20,22 e 26).

\section{- Relacionado a ter amigo:}

Amizade é: “Ter amigos em quem confiar”, “quando é amizade, é bom”, “ter amigos”, "poder confiar em outras pessoas", "è muito bom ter amigos”, "muito bom adoro ter amizade”. (S: 10, 13, 16, 18,22 e 25).

\section{- Relacionado a algo importante:}

Amizade é: “A coisa mais importante”, "Uma coisa importante, distrai”, “A coisa mais importante”. (S: 04,23 e 24). 


\section{- Relacionado a outros indicadores:}

Amizade é: "Viver em paz sem brigar com ninguém”, "Lealdade e respeito”, "Sentimento fiel de afeição”, “hoje uma conquista”, “bater papo”, “Muito prazer”, “muita alegria”, “bater papo”, “ter alegria”, “distrai”, “é o principal”, “honestidade”. (S: 02, 05, 06, 11, 12, 17, 19,20 e 21).

Os relacionamentos pessoais são deveras importantes para os idosos, à representação da amizade, relacionada nas questões acima, nos chamou à atenção o quanto isso é importante para eles. O lazer, bem como o turismo, uma de suas vertentes, que são atividades voltadas ao desenvolvimento pessoal e social (REQUIXA, 1980). Devem ser amplamente utilizados, para a promoção e fortalecimento de laços de amizade e companheirismo no contexto social do idoso.

Grupos, como o PIC, possibilitam o aumento do ciclo de amizade dos idosos, que muitas vezes fica comprometido com o passar dos anos. Ali os idosos encontram seus companheiros para diversas atividades, as que ali são desenvolvidas, bem como, outras que podem ser programadas por eles mesmos, encontram ali seus confidentes, com quem muitas vezes passam grande parte de seu tempo. A amizade pode proporcionar ao idoso uma vida mais humana, completa e mais feliz.

Além disso, ao construir e ou estreitar laços de amizade, em seu tempo livre, em que se dedica ao lazer e turismo, o idoso pode encontrar determinados efeitos, como descanso físico ou mental (MARCELLINO, 1990). 
Quadro 10 - Representação qualitativa das respostas das falas dos idosos pesquisados sobre as questões: Como você tem visto a violência hoje? Isto prejudica o seu lazer?

\begin{tabular}{|c|c|c|c|c|}
\hline \multirow{2}{*}{ Sujeitos } & \multirow{2}{*}{$\begin{array}{l}\text { Como você tem visto a violência hoje? } \\
\text { Respostas: }\end{array}$} & \multicolumn{3}{|c|}{ Isto prejudica o seu lazer? } \\
\hline & & Sim & Não & Respostas: \\
\hline 01 & Muito triste & $\mathrm{X}$ & & Fico preocupada \\
\hline 02 & O bolso vazio faz o cara ficar violento & & $\mathrm{X}$ & \\
\hline 03 & Triste & & $\mathrm{X}$ & \\
\hline 04 & --- & & $\mathrm{X}$ & \\
\hline 05 & Preocupante & $\mathrm{X}$ & & \\
\hline 06 & Um desastre para a humanidade & $\mathrm{X}$ & & Se ficar pensando muito nela \\
\hline 07 & Muito triste & $\mathrm{X}$ & & Não fico segura \\
\hline 08 & Com muita tristeza & & $\mathrm{X}$ & \\
\hline 09 & Preocupante & $\mathrm{X}$ & & \\
\hline 10 & --- & $\mathrm{X}$ & & \\
\hline 11 & Ruim, mau & & $\mathrm{X}$ & \\
\hline 12 & Medo & $\mathrm{X}$ & & \\
\hline 13 & Medo & $\mathrm{X}$ & & \\
\hline 14 & Grave & $\mathrm{X}$ & & \\
\hline 15 & Está fora do normal & $\mathrm{X}$ & & Assim a gente não tem tranquilidade \\
\hline 16 & Com preocupação & & $\mathrm{X}$ & \\
\hline 17 & Com muita preocupação & $\mathrm{X}$ & & Em termos \\
\hline 18 & Preocupante & $\mathrm{X}$ & & \\
\hline 19 & É muito triste & $\mathrm{X}$ & & \\
\hline 20 & Brutalmente & & $\mathrm{X}$ & Por enquanto não \\
\hline 21 & Péssima & $\mathrm{X}$ & & Porque não ando tranqüilo \\
\hline 22 & Tá demais & $\mathrm{X}$ & & Fico triste \\
\hline 23 & Horrível, não tem jeito nem de ver TV & $\mathrm{X}$ & & $\begin{array}{l}\text { Prejudica porque não podemos sair } \\
\text { de casa a qualquer hora, até o trânsito } \\
\text { tá violento }\end{array}$ \\
\hline 24 & A violência assusta & $\mathrm{X}$ & & Tenho medo \\
\hline 25 & É fogo é demais & $\mathrm{X}$ & & Prejudica muito \\
\hline 26 & Péssima o fim do mundo & $\mathrm{X}$ & & Sou de idade, tenho medo das drogas \\
\hline
\end{tabular}

No Quadro 10 os dados nos permitem chegar a seguinte classificação, caracterizando o significado da violência relacionado à negatividade à preocupação e ao medo.

\section{CARACTERIZAÇÃO RELATIVA AO SIGNIFICADO DA VIOLÊNCIA:}

- Algo ligado à negatividade:

A violência é: "Um desastre para a humanidade”, "grave”, "está fora do normal”, “brutalmente”, “péssima”, “tá demais”, “horrível”, “triste”, “ruim”, “um mau”, “não tem jeito nem de ver tv", "a violência assusta”, "é fogo é demais”, "péssima o fim do mundo”(S: $01,02,03,06,07,08,14,15,19,20,21,22,23,24,25$ e 26$)$.

- Algo ligado à preocupação:

A violência é: “Preocupante”, “com muita preocupação”(s:05,09,16,17 e 18).

- Algo ligado a medo:

A violência é: “Com medo” (S:12 e 13). 
Ao serem questionados se a violência prejudica seu lazer, o Quadro 10, mostra o seguinte:

\section{A GRANDE MAIORIA REFERIU QUE PREJUDICA SIM, O SEU LAZER:}

- Há preocupação:

Prejudica: “Fico preocupada”, “se ficar pensando muito nela”, “não fico segura”, “assim a gente não tem tranqüilidade”, “em termos”, “porque não ando tranqüilo”, “fico triste”, “prejudica porque não podemos sair de casa a qualquer hora”, "até o trânsito tá violento”, "tenho medo", “prejudica muito”, “sou de idade”, "tenho medo das drogas”. (S:01,06,07,15,17,21,22,23,24,25 e 26).

A grande maioria refere ter medo da violência. Todavia apenas o (S:20) refere não ter preocupação ainda com isso. A violência constitui nitidamente, um grave problema social. É oriunda de diversas variáveis como a pobreza, desigualdades sociais, globalização entre outras. Constitui-se em um grande estressor da atualidade, ou seja, expostos a ela, ou a eminência de sua ocorrência, desenvolvemos respostas emocionais que podem afetar nossa saúde como um todo (INSEL, ROTH, 2006).

Observando então, as categorias obtidas através das repostas dos idosos quanto à violência, pudemos verificar que essa situação os afeta sim, no plano mental, e que, além disso, vêm a afetar também suas atividades de lazer, ou seja, a violência também os afeta no

plano social. À medida que reduz sensivelmente os espaços de lazer e recreação na cidade, assim como o tempo para desfrutá-los, o que também afeta a saúde ao limitar os lugares seguros onde as pessoas inclusive o idoso, possam realizar atividades de lazer incluindo as turísticas.

Afeta o cotidiano e a liberdade de movimento, bem como o direito de desfrutar os bens públicos. 
A violência e os problemas de saúde mental estão intrinsecamente associados, podem ser sua expressão e podem ser também sua causa. As relações entre ambos são complexas, mas há provas de que os diversos tipos de violência podem contribuir para diminuição da saúde mental e para o aumento significativo de vários transtornos mentais, entre eles a depressão, a ansiedade, o uso e abuso de álcool e outras drogas ilícitas, os transtornos psicossomáticos e o suicídio (WHO, 2003).

Ocorrem ainda atualmente incidentes violentos envolvendo muitos idosos, eles têm sido vítimas da violência urbana, pois por apresentarem certa fragilidade física, muitas vezes se tornam alvos fácies dos infratores.

Acreditamos ser necessário que políticas voltadas à prevenção da saúde do idoso, que englobe a questão da violência como tema a ser trabalhado, na busca de minimizar os malefícios que a mesma acarreta ao idoso.

Quadro 11 - Representação qualitativa das respostas das falas dos idosos pesquisados sobre a questão: $O$ que você faria para evitar esta violência?

\begin{tabular}{|c|c|}
\hline Sujeitos & O que você faria para evitar esta violência? \\
\hline 01 & Rezo e pedir a Deus para ter sorte \\
\hline 02 & INPS atender todo mundo \\
\hline 03 & Tudo \\
\hline 04 & Tudo \\
\hline 05 & Preocupante \\
\hline 06 & Tentaria mudar o mundo \\
\hline 07 & Ter mais fé em Deus \\
\hline 08 & Educaria as crianças \\
\hline 09 & Mais trabalho e religião \\
\hline 10 & --- \\
\hline 11 & Não sei \\
\hline 12 & Mais segurança \\
\hline 13 & Mais segurança \\
\hline 14 & Rezar \\
\hline 15 & Mudar a lei e dar educação \\
\hline 16 & Nada \\
\hline 17 & Aumentar a segurança \\
\hline 18 & Investimento na Educação e emprego \\
\hline 19 & Aconselhar e conversar \\
\hline 20 & Através da religião, pensar em Deus \\
\hline 21 & Leis mais duras \\
\hline 22 & $\begin{array}{l}\text { Essa violência vem das drogas, mas não tem jeito de acabar, } \\
\text { perdi um filho de } 17 \text { anos por causa das drogas, fiz de tudo. }\end{array}$ \\
\hline 23 & Reeducar as pessoas \\
\hline 24 & Eu não sei, só peço ajuda a Deus \\
\hline 25 & Faria muita coisa, mas não posso fazer nada \\
\hline 26 & Acho muito difícil dar um jeito \\
\hline
\end{tabular}




\section{CATEGORIZAÇÃO SOBRE A PREVENÇÃO CONTRA A VIOLÊNCIA:}

Aqui, houve possibilidade de classificar a respostas relacionando- as a religiosidade, educação e outras soluções.

\section{- Atividades voltadas à religião/deus:}

Eu procuraria: “Religião”, “fé”, “rezar”, “pedir e pensar em Deus”, "ter mais fé em Deus” (S:01,07,09,14,20 e 24).

\section{- Atividades ligadas a educação:}

Eu procuraria: “Educação", “investimento em educação”, "reeducar as pessoas”, “aconselhar e conversar”, “mudar a lei, leis mais duras” (S:08,15,18,19, 21 e 23).

\section{- Atividades voltadas a outras soluções:}

“INPS atender todo mundo”, “tudo”, “preocupante”, “tentaria mudar o mundo”, “não sei”, “mais segurança”, “nada”, “aumentar a segurança”, "essa violência vem das drogas”, “mas não tem jeito de acabar, perdi um filho de 17 anos por causa das drogas, fiz de tudo" (S: 02,03,04,05,06,11,12,13,16,17 e 22).

A sociedade atualmente sofre com uma série de modificações em sua estrutura, muitas são tidas como benéficas e outras estão muito longe disso. A violência conforme dito anteriormente é oriunda dessas transformações da contemporaneidade. Episódios violentos podem sim ocorrer no nosso cotidiano, no trânsito, no trabalho (abuso de poder); durante nossas atividades de lazer, para os idosos a queda é um grande exemplo de episódio violento (INSEL, ROTH, 2006). Porém o que mais os preocupam é realmente a violência urbana, vinda dos problemas sociais tão evidentes atualmente.

Para muitos, inclusive para os idosos, essas transformações são de difícil compreensão, à medida que a violência abala as relações e a estrutura social, produzindo e gerando danos ao fomentar comportamentos e atitudes que minam as bases e princípios de convivência e resolução de conflitos (WHO, 2003). 
A grande maioria dos idosos aponta a religião e a educação como chaves para evitar a violência.

Acreditamos que esses valores, deveras importantes, significam para eles o retorno aos valores entendidos como sólidos e responsáveis capazes de reverter o quadro atual. Todavia, é obvio que a adoção de medidas simples não irá acabar com a violência.

Abordando a questão da Educação, acreditamos que ela pode ser uma importante estratégia, na luta contra a violência, a medida que a Educação possibilita a adoção de medidas positivas, vinculadas a transformação. Pode não ser um processo rápido e nem fácil, mas envolve também a adoção de políticas públicas voltadas à otimização da vida e promoção de saúde física e mental de todos os cidadãos (WHO, 2001).

Quadro 12 - Representação qualitativa das respostas das falas dos idosos pesquisados sobre as questões: Você gosta de música? Você gosta de dançar?

\begin{tabular}{|l|l|l|l|}
\hline \multirow{2}{*}{ Sujeitos } & $\begin{array}{l}\text { Você gosta de } \\
\text { música? }\end{array}$ & $\begin{array}{l}\text { Você gosta de } \\
\text { dançar? }\end{array}$ & \\
\cline { 2 - 4 } & Sim & Sim & Não \\
\hline 01 & $\mathrm{X}$ & $\mathrm{X}$ & \\
\hline 02 & $\mathrm{X}$ & & $\mathrm{X}$ \\
\hline 03 & $\mathrm{X}$ & $\mathrm{X}$ & $\mathrm{X}$ \\
\hline 04 & $\mathrm{X}$ & $\mathrm{X}$ & \\
\hline 05 & $\mathrm{X}$ & $\mathrm{X}$ & \\
\hline 06 & $\mathrm{X}$ & $\mathrm{X}$ & \\
\hline 07 & $\mathrm{X}$ & $\mathrm{X}$ & \\
\hline 08 & $\mathrm{X}$ & $\mathrm{X}$ & \\
\hline 09 & $\mathrm{X}$ & $\mathrm{X}$ & \\
\hline 10 & $\mathrm{X}$ & $\mathrm{X}$ & \\
\hline 11 & $\mathrm{X}$ & $\mathrm{X}$ & $\mathrm{X}$ \\
\hline 12 & $\mathrm{X}$ & & \\
\hline 13 & $\mathrm{X}$ & $\mathrm{X}$ & \\
\hline 14 & $\mathrm{X}$ & $\mathrm{X}$ & $\mathrm{X}$ \\
\hline 15 & $\mathrm{X}$ & & $\mathrm{X}$ \\
\hline 16 & $\mathrm{X}$ & & $\mathrm{X}$ \\
\hline 17 & $\mathrm{X}$ & & \\
\hline 18 & $\mathrm{X}$ & $\mathrm{X}$ & \\
\hline 19 & $\mathrm{X}$ & $\mathrm{X}$ & $\mathrm{X}$ \\
\hline 20 & $\mathrm{X}$ & & \\
\hline 21 & $\mathrm{X}$ & $\mathrm{X}$ & \\
\hline 22 & $\mathrm{X}$ & $\mathrm{X}$ & \\
\hline 23 & $\mathrm{X}$ & $\mathrm{X}$ & $\mathrm{X}$ \\
\hline 24 & $\mathrm{X}$ & $\mathrm{X}$ & \\
\hline 25 & $\mathrm{X}$ & $\mathrm{N}$ & \\
\hline 26 & $\mathrm{X}$ & & \\
\hline & & & \\
\hline
\end{tabular}


No que concerne à questão se gosta de música e dança, de acordo com o Quadro 12, todos os sujeitos responderam que gostam de música. Da mesma forma, a grande maioria também respondeu que gostam de dançar.

As atividades ligadas à dança e a música podem constituir um importante meio de realização pessoal do idoso, nesse período é importante que o idoso se dedique ao que mais goste de fazer, podendo expandir seus horizontes, ter a chance de realizar novas atividades e conhecer novas pessoas (INSEL, ROTH, 2006).

Como o lazer é uma escolha individual, momento em que as pessoas podem desfrutar prazeres é importante que o idoso realize atividades que lhe faça bem, que o torne realizado.

Muitos idosos ao sofrerem as transformações da velhice, aceitam as idéias de declineo. Tornando-se realmente velhos, deixam de fazer o que estavam acostumados. Essa situação ainda se agrava com as limitações reais do envelhecimento, atividades como a dança muitas vezes pode ser abandonada, à medida que algumas pessoas atribuem essa atividade aos mais jovens (DIAS, SCHWARTZ, 2005).

Constituindo então um grande equívoco, visto que a dança é uma atividade extremamente prazerosa e integradora. Além de que faz parte das atividades associativas de lazer, constituindo então um forte conteúdo de sociabilidade, expresso no contato com os amigos, vizinhos ou colegas, afastando o idoso da solidão (CAMARGO, 1999).

Quanto à música, ela pode simplesmente significar contemplação, sendo apenas uma das atividades prazerosas de lazer, mas pode também ser enquadrada nas atividades artísticas de lazer, uma fonte de expressão, para si, para os amigos e para a família (CAMARGO, 1999).

É uma atividade de desenvolvimento intelectual, indo ao encontro da terceira função do lazer, a função de desenvolvimento pessoal, que possibilita ao indivíduo a cultura desinteressada, possibilitando novas oportunidades de integração com a comunidade, uma nova forma de aprendizagem, construindo assim um novo estilo de vida (DUMAZEDIER, 2000). 
Quadro 13 - Representação qualitativa das respostas das falas dos idosos pesquisados sobre as questões: $O$ que traz alegria para você? $O$ que você sonha para si?

\begin{tabular}{|l|l|l|}
\hline Sujeitos & O que traz alegria para você? & O que você sonha para si? \\
\hline 01 & Dançar, ir para o parque, ver netos e bisnetos & Peço a Deus saúde e uma morte tranquila \\
\hline 02 & Ama Deus & Nada já tô feliz \\
\hline 03 & Dançar, passear & Fica rica \\
\hline 04 & A família & Ter saúde \\
\hline 05 & Os amigos & Viajar mais \\
\hline 06 & Ver as pessoas felizes & Nada de especial \\
\hline 07 & Saúde e paz & Ter uma velhice saudável \\
\hline 08 & Saúde, música, dança, família & Muita amizade, saúde e alegria \\
\hline 09 & Viver bem em família e boa saúde & Paz \\
\hline 10 & Estar tudo bem & Muita saúde \\
\hline 11 & Família, amigos, Igreja & São tantas coisas... \\
\hline 12 & Viver com filho & Novo futuro \\
\hline 13 & Quando estou com filho & Novo futuro \\
\hline 14 & Paz na família & Ter paz \\
\hline 15 & Colaborar com a comunidade & Ver os netos crescer, formados \\
\hline 16 & Família, saúde de todos & --- \\
\hline 17 & Sinceridade dos amigos & Viver mais alguns anos \\
\hline 18 & Conviver com a família, viajar & Tranqüilidade e saúde na terceira idade \\
\hline 19 & Netos, filhos, fim de ano & Continuar a ter alegria, animação \\
\hline 20 & Família, diversão & Felicidade da minha filha e de sua família \\
\hline 21 & Tudo que for bom, ver as pessoas felizes & Saúde \\
\hline 22 & Divertimento, reunião com a família & Não sonho mais nada, já estou de idade \\
\hline 23 & Estar bem, passear e sair de casa & Sonho em ter um fim sem sofrimento \\
\hline 24 & Viver bem & Sonho ver todos alegres e contentes \\
\hline 25 & Tudo, principalmente saúde & Um dia melhor \\
\hline 26 & Sair, conversar e dançar & Nada, já estou de idade \\
\hline & & \\
\hline
\end{tabular}

\section{CATEGORIZAÇÃO O QUE LHE TRAZ ALEGRIA:}

\section{- Relacionado à família:}

Alegria pra mim é: “a família”, "estar com a família”, “filhos”, "ver netos e bisnetos”, "viver bem em família”, "paz na família”, "viver bem com o filho”, "quando estou com o filho”, "paz na família”, “conviver com a família”, “netos”, "filhos, fim de ano”, "reunião com a família”. (S:01,04,07, 08,09,11,12,13,14,16,18,19,20 e 22).

\section{- Relacionado ao bem-estar:}

Alegria pra mim é: “estar bem”, “viver bem”, “estar tudo bem”, "tudo que for bom”, "ver as pessoas felizes" (S: 06, 10,21,23 e 24).

\section{- Relacionado à saúde:}

Alegria pra mim é: “saúde”, "boa saúde”, "principalmente saúde”, saúde de todos” (S:07,08,09,16 e 25). 


\section{- Relacionado à música e a dança:}

Alegria pra mim é: “música”, “dançar” (s:01,03,08 e 26).

- Relacionado à amizade:

Alegria pra mim é: “os amigos”, “amigos”, “sinceridade dos amigos” (s:05,11, 17).

- Relacionado ao passeio e diversão:

Alegria pra mim é: “ir ao parque”, "passear”, “viajar”, "passear e sair de casa”, "sair, conversar”, “diversão”, “divertimento” (S:01,03, 18,20,22,23 e 26).

- Relacionado a religião:

Alegria pra mim é: “igreja”, “amar a Deus”, “paz” (s:02 , 07 e 11).

- Relacionado a outros:

Alegria pra mim é: “colaborar com a comunidade”, “tudo” (S:15 e 25).

A maneira como o idoso se relaciona com o seu meio, sem dúvida faz a diferença na maneira como ele encara a vida e como ele vive, realmente. A sua felicidade vai depender dessa relação. São fatores determinantes na busca de alegria para o idoso, o seu estado de habitação, condições financeiras, desenraizamento do meio habitual como o afastamento físico de familiares e amigos. A relação do idoso com a família é sem dúvida muito importante para manutenção e busca de sua alegria. As relações familiares dependem muito do que foram ontem, ou seja, relações sólidas possibilitam uma maior interação na velhice (RUIPEREZ; LLORENTE, 2001).

No demais, os idosos que têm bom relacionamento familiar tem a possibilidade de integração, convivência, preenchimento de seus dias de uma maneira agradável e prazerosa.

Quanto a sentir-se bem e a questão da saúde, ambas estão ligadas a boa adaptação ao envelhecimento, preparar-se apropriadamente para esse momento pode trazer ao idoso uma capacidade de adaptação adequada, diminuindo as perdas características do envelhecimento. 
Aprender a aceitar o envelhecimento é difícil, porém importante, para facilitar esse processo é necessário informação, posturas positivas e comprometimento, otimizando dessa maneira esse período da vida, podendo sim encontrar alegria (INSEL, ROTH, 2006).

As questões sócio-culturais têm papel importante na alegria do idoso, o lazer englobando nesse momento a música, dança, passeio e diversão bem como os aspectos religiosos podem ser parte da adaptação e reorganização da vida do idoso, na busca de sua alegria e saúde, conseqüentemente de seu bem-estar.

\section{CATEGORIZAÇÃO O QUE VOCÊ SONHA PARA SI:}

- Relacionado à saúde:

Sonho para mim: "peço a Deus saúde”, "saúde”, "ter saúde”, “muita saúde”, "ter uma velhice saudável”, “ter saúde na terceira idade” (S:01,04,07,08,10,18 e 21).

- Relacionado a nada de especial:

Sonho para mim: “não sonho mais nada já estou de idade”, "nada já estou feliz”, "nada de especial” (S:02,06,22 e 26).

- Relacionado ao um novo futuro:

Sonho para mim: "um novo futuro", "um dia melhor” (S:12,13 e 25).

- Relacionado à alegria:

Sonho para mim: “alegria”, “continuar a ter alegria e animação”, "sonho em ver todos alegres e contentes” (S:08,19 e 24).

- Relacionado à paz:

Sonho para mim: “paz”, “ter paz” (S:09 e 14).

- Relacionado à boa morte:

Sonho para mim: “sonho em ter um fim sem sofrimento”, “uma morte tranqüila” (S:01 e 23). 


\section{- Relacionado à família:}

Sonho para mim: "felicidade da minha filha e de sua família”, “ver os netos crescer, formados” (S:15 e 20).

\section{- Relacionado a outros:}

Sonho para mim: "são tantas coisas”, "viver mais alguns anos”, “um dia melhor”, "ficar rica”, “viajar mais”, “muita amizade”, “tranqüilidade” (S:03,05,08,11,17,18 e 25).

Os idosos muitas vezes admitam não sonhar mais, ou ao dizerem nada de especial, muitos consideram que realizaram o que podiam durante a vida. Essa posição não deveria ser tão hermética, acreditamos que sempre é tempo de sonhar e realizar coisas novas. A capacidades de sonhar induz a esperança, aprimoramento e ressignificação de sua vida. Acreditamos que essa realidade está atrelada a nossa cultura e nossa sociedade, que muitas vezes não permite ao idoso a vontade e a busca da realização de seus projetos e desejos.

Mas, atualmente o idoso vem tendo diversas oportunidades, inclusive no contexto do lazer, de ressignificar sua existência, sua aprendizagem e sua importância como cidadão, tendo sim o direito de sonhar (GÁSPARI, SCHWARTZ, 2005).

O sonho relacionado à esperança de boa saúde é facilmente compreendido, pois os idosos têm perdas relacionadas ao envelhecimento biológico que são drásticas (RODRIGUES; DIOGO; BARROS, 2004).

Adotar hábitos saudáveis, alimentação balanceada, cuidados com o peso, não fumar, praticar exercícios físicos regularmente e realizar controles e diagnósticos de saúde anualmente, são comportamentos que podem otimizar o seu bem-estar, sendo que muitos idosos já possuem essa consciência (INSEL, ROTH, 2006).

Baseado nesses pressupostos acreditamos que é importante para o idoso sonhar com um novo futuro, vislumbrando alegria e paz, à medida que assim ele segue sua vida 
combatendo a idéia de sedentarismo, apatia e desolamento.

Sendo assim, ele combate à falta de perspectivas diante do envelhecimento, aos poucos, ela vai perdendo espaço para a crescente participação e adesão às inúmeras oportunidades, que são oferecidas ao segmento idoso nos espaços públicos e/ou privados, formal e/ou informal, ressignificando sua existência (GÁSPARI, SCHWARTZ, 2005).

Por outro lado, a morte é uma preocupação recorrente na vida do idoso, a boa morte é um desejo real, a idéia de dor e sofrimento os faz almejar por uma morte tranqüila. Primeiramente é importante aceitar que a morte é um processo inerente a vida e inevitável. Podemos nos assegurar de alguma maneira, tentando dar mais atenção aos aspectos que envolvem a nossa existência e tentar se preparar para sua chegada (INSEL, ROTH, 2006).

A questão da família, conforme dita anteriormente, é muito importante na vida do idoso, com certeza sonhos e planos para o seu futuro devem incluí-la, a família muitas vezes é o seu "porto seguro". Tanto o idoso quanto seus familiares devem se adaptar as mudanças e as esperanças nessa fase (RUIPEREZ; LLORENTE, 2001).

Quadro 14 - Representação qualitativa das respostas das falas dos idosos pesquisados sobre as questões: $O$ que significa sua vida hoje?

\begin{tabular}{|l|l|}
\hline Sujeitos & O que significa sua vida hoje? \\
\hline 01 & Maravilhosa, agradeço a todo momento a Deus \\
\hline 02 & Uma benção \\
\hline 03 & Bem \\
\hline 04 & --- \\
\hline 05 & Alegria felicidade \\
\hline 06 & Uma benção de Deus \\
\hline 07 & Ótima \\
\hline 08 & Para mim significa muito, sou feliz \\
\hline 09 & Muito amor porque creio em Deus \\
\hline 10 & Boa \\
\hline 11 & Completa \\
\hline 12 & Muito boa \\
\hline 13 & Sinto muito boa \\
\hline 14 & Tudo \\
\hline 15 & Muitas esperanças \\
\hline 16 & Feliz \\
\hline 17 & Uma dádiva de Deus \\
\hline 18 & Preocupação com a terceira idade \\
\hline 19 & Ė muito boa \\
\hline 20 & Trabalhar e ter sempre um objetivo maior \\
\hline 21 & Uma batalha, mas boa \\
\hline 22 & Graças a Deus estou aposentada \\
\hline 23 & Queria ser mais nova para fazer mais coisas \\
\hline 24 & A minha vida é importante \\
\hline 25 & Ótima, boa, depois que fiquei viúva \\
\hline 26 & Alegria, felicidade, amizade e PIC \\
\hline
\end{tabular}




\section{CATEGORIZAÇÃO DO SIGNIFICADO DA VIDA ATUAL:}

- Relacionado à religião:

Minha vida significa: “uma dádiva de Deus”, “agradeço a Deus todo momento”, "uma benção”, “uma benção de Deus”, “muito amor porque creio em Deus”, "graças a Deus estou aposentada” (S:01,02,06,09,17 e 22).

\section{- Relacionado ao bom e a ótimo:}

Minha vida significa: "boa”, "bem”, “completa”, “ótima”, “muito boa”, "me sinto muito boa”, “é muito boa”, “uma batalha, mas boa” (S:03,07,10,11,12,13,19,21 e 25).

- Relacionado à alegria e felicidade:

Minha vida significa: “sou feliz”, “sou muito feliz”, “felicidade” (S:05,08,16 e 26).

\section{- Relacionado à importância:}

Minha vida significa: "para mim significa muito”, "minha vida é muito importante” (S:08 e 24).

\section{- Relacionado a outros:}

Minha vida significa: “PIC”, “amizade”, “maravilhosa”, “queria ser mais nova para fazer mais coisas", "tudo", "muitas esperanças", "preocupação com a terceira idade”, “trabalhar e ter sempre um objetivo maior” (S:01,14,15,18,20,23 e 26).

Os idosos questionados ao significado de sua vida hoje demonstraram ligação a religiosidade. Pudemos observar que esse é realmente um aspecto presente em suas vidas. Fato que consideramos importante pois a relação entre religiosidade e saúde mental vem sendo estudada a muitos séculos, sendo encontradas evidências entre saúde mental e religião, ao passo que essa relação possibilita a diminuição de episódios depressivos, suicídio e uso abusivo de álcool e outras drogas por exemplo, além de que a religiosidade afasta o idoso do isolamento social, favorecendo a idéia de um suporte social, ajudando na promoção de sua 
saúde mental (MOREIRA-ALMEIDA; LOTUFO NETO; KOENIG, 2006).

Além dos aspectos religiosos os idosos demonstraram dar importância a sua vida, atribuindo valores relacionados ao bom e ao ótimo, alegria e algo importante, nos fazendo interpretar que os freqüentadores do PIC estão bem, que eles valorizam sua existência e possuem boa auto-estima, algo muito importante para sua saúde. A atividade grupal facilitando a ampliação da rede social do idoso, é tida como pertinente para a ressignificação dos valores negativos associados ao processo de envelhecimento, bem como os esteriótipos que ele acarreta (TEIXEIRA, 2002).

Apareceram respostas relacionadas a amizade e coisas maravilhosas. Alguns relataram preocupações com a idade, algo perfeitamente compreensível nesse período da vida. Mas o que realmente prevaleceu foi a boa impressão que eles atribuem ao significado de suas vidas.

\section{Quadro 15 - Representação qualitativa das respostas das falas dos idosos pesquisados sobre: Livre para você falar o que quiser.}

\begin{tabular}{|c|c|}
\hline Sujeitos & Livre para você falar o que quiser? \\
\hline 01 & Adoro vir no PIC, participar da igreja e adoro ficar com os meus neto \\
\hline 02 & Eu queria que o INPS atendesse à todos, a gente ganha pouco \\
\hline 03 & PIC muito bom pra mim caminhar dançar \\
\hline 04 & PIC muito bom, amizades \\
\hline 05 & Sou feliz com a família e amigos \\
\hline 06 & Boa pesquisa \\
\hline 07 & Divertir \\
\hline 08 & Obrigado \\
\hline 09 & Ter bom atendimento na saúde \\
\hline 10 & --- \\
\hline 11 & Não sei \\
\hline 12 & Não tenho o que dizer \\
\hline 13 & Não tenho o que dizer \\
\hline 14 & Paz na terra \\
\hline 15 & Muito obrigado pelas pergumtas \\
\hline 16 & --- \\
\hline 17 & Parabéns pela pesquisa \\
\hline 18 & --- \\
\hline 19 & O PIC é uma família não tenho nada a reclamar \\
\hline 20 & Gostaria de mais atividades no PIC, como bordado, pintura e crochê \\
\hline 21 & Nada está tudo ok \\
\hline 22 & Lazer e turismo aqui no PIC faz muito bem, chego aqui e me sinto bem \\
\hline 23 & $\begin{array}{l}\text { Depois que comecei a vir no PIC melhorou a minha saúde, a minha cabeça é outra coisa, todas as atividades que } \\
\text { faço aqui melhora minha saúde }\end{array}$ \\
\hline 24 & O PIC é muito importante para mim, venho aqui há dez anos \\
\hline 25 & O bom é ter saúde, família e passear \\
\hline 26 & Me sinto feliz quando estou perto da minha família \\
\hline
\end{tabular}




\section{CATEGORIZAÇÃO DA LIVRE EXPRESSÃO PARA EXPRESSAR SOBRE O QUE QUISER:}

- Relacionado ao PIC:

"Adoro vir ao PIC, é muito bom para caminhar, dançar”, "O PIC é bom por causa das amizades”, “O PIC é uma família não tenho nada a reclamar”, "lazer e turismo aqui no PIC faz muito bem, chego aqui e me sinto bem", "Depois que comecei a vir no PIC melhorou a minha saúde”, "gostaria de mais atividades no PIC, como bordado, pintura e crochê", "a minha cabeça é outra coisa, todas as atividades que faço aqui melhora minha saúde”, "o PIC é muito importante para mim, venho aqui há dez anos” (S:01,03,04,19,22,23 e 24).

\section{- Relacionado à família e a amizade:}

“sou feliz com a família e amigos”, "família”, “adoro ficar com meus netos”, “me sinto feliz quando estou perto da minha família” (S:01,05,25 e 26).

- Relacionado à pesquisa:

“obrigado", “muito obrigado pelas pergunta”, “boa pesquisa”, "parabéns pela pesquisa”(S:06,08,15 e 17).

- Relacionado à saúde:

“o bom é ter saúde”, “ter bom atendimento na saúde”(S:09 e 25).

- Relacionado a não ter o que dizer:

“não tenho o que dizer” (S:12 e 13).

- Relacionado a outros:

“passear”, “divertir”, “eu queria que o INPS atendesse à todos, a gente ganha pouco”, "paz na terra”, “participo da igreja”, “nada, está tudo ok” (s:01,02,07,14,21 e 25)).

A questão aberta, proposta aos idosos, que tinha como função deixá-los à vontade para se expressarem livremente evidenciou a importância do PIC em suas vidas, alguns relacionaram o PIC com as atividades de lazer e turismo, ou seja, as atividades que o 
programa executa, mas mais que isso, encontramos relação do programa e das atividades ali desenvolvidas com a otimização de suas vidas, no momento que atribuem ao PIC, a melhoria de sua saúde e de seu bem estar. Nessa mesma categoria, encontramos sugestões voltadas à melhoria do programa, nada substancial.

A questão da família e dos amigos voltou a ser mencionada, interligando a presença e convivência dos amigos e familiares a sentimentos positivos.

Alguns idosos mencionaram apontamentos positivos à pesquisa e agradecimentos por fazerem parte dela. A saúde foi bastante mencionada também, visto que a preocupação com a saúde é uma constante entre os idosos.

Estes foram os apontamentos mais significativos relacionado à questão aberta.

\section{C - PROGRAMA EDUCATIVO}

Quadro 1 - Representação qualitativa das respostas das falas dos idosos pesquisados sobre a questão: $O$ que você gostaria que eu falasse com você sobre o assunto Lazer e Turismo, como educação para sua saúde física e mental? E de que forma poderíamos trabalhar juntos essa questão?

\begin{tabular}{|c|c|}
\hline Sujeitos & Temas geradoreslevantados: \\
\hline 01 & Queria saber mais sobre lazer e turismo \\
\hline 02 & Não tenho nada a dizer. \\
\hline 03 & Explicar o que é lazer, viajar, dançar \\
\hline 04 & ---- \\
\hline 05 & Explicação sobre lazer e turismo. \\
\hline 06 & $\begin{array}{l}\text { Gostaria de ter um conhecimento melhor sobre turismo e lazer para uma qualidade de vida melhor e poder } \\
\text { transmitir aos meus netos sendo possível fazê- lo com um diálogo }\end{array}$ \\
\hline 07 & ---- \\
\hline 08 & Gostaria de conhecê- la mais para conversarmos, trabalhei 31 anos no Hospital Pisiquiátrico \\
\hline 09 & 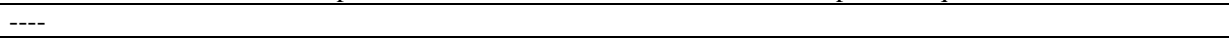 \\
\hline 10 & ---- \\
\hline 11 & ---- \\
\hline 12 & A ginástica é muito importante. \\
\hline 13 & Ginástica \\
\hline 14 & ---- \\
\hline 15 & ---- \\
\hline 16 & ---- \\
\hline 17 & $\begin{array}{l}\text { Passar seu conhecimento sobre o assunto, para melhorar ainda mais minha saúde física e mental. Poderíamos } \\
\text { trabalhar juntos, dialogando sobre o assunto. }\end{array}$ \\
\hline 18 & Tenho problema de coluna que me impede de programar viagens longas (aspecto físico) \\
\hline 19 & Gostaria que fosse incluso no PIC a natação \\
\hline 20 & Melhorar as atividades de lazer no PIC, para ativar a cabeça \\
\hline 21 & --- \\
\hline 22 & $\begin{array}{l}\text { Conversar sobre o PIC, sobre o que a gente faz, sobre lazer e turismo, pois é muito bom para gente se } \\
\text { distrair }\end{array}$ \\
\hline 23 & Explicar a importância do lazer e do turismo para minha saúde \\
\hline 24 & Sobre envelhecimento, lazer e turismo \\
\hline 25 & Falar sobre coisas que interessam para gente, sobre saúde e turismo \\
\hline 26 & Sobre a minha idade, na minha cabeça eu não tenho essa idade \\
\hline
\end{tabular}




\section{CATEGORIZAÇÃO SOBRE OS TEMAS GERADORES:}

- Relacionado ao lazer e ao turismo:

Respostas: "queria saber mais sobre lazer e turismo", "explicar o que é lazer, viajar, dançar”, “explicação sobre lazer e turismo”, "gostaria de ter um conhecimento melhor sobre turismo e lazer para uma qualidade de vida melhor e poder transmitir aos meus netos sendo possível fazê- lo com um diálogo”, “a ginástica é muito importante”, "ginástica”, “conversar sobre o PIC, sobre o que a gente faz, sobre lazer e turismo, pois é muito bom para gente se distrair", "sobre lazer e turismo", "falar sobre coisas que interessam para gente, turismo” (S:01,03,05,06,12,13,22,24 e 25).

- Relacionado a saúde mental:

Respostas: “falar sobre coisas que interessam pra gente, saúde”, "melhorar as atividades de lazer no PIC, para ativar a cabeça”, "passar seu conhecimento sobre o assunto, para melhorar ainda mais minha saúde física e mental poderíamos trabalhar juntos, dialogando sobre o assunto", "explicar a importância do lazer e do turismo para minha saúde” (S:17,20,23 e 25).

\section{- Relacionado ao envelhecimento:}

Respostas: "tenho problema de coluna que me impede de programar viagens longas (aspecto físico)", "sobre a minha idade, na minha cabeça não tenho essa idade”, "sobre envelhecimento" (S:18 e 26).

\section{- Relacionado a outros:}

Respostas: “Gostaria que fosse incluso no PIC a natação”, “Gostaria de conhecê- la mais para conversarmos, trabalhei 31 anos no Hospital Pisiquiátrico", "não tenho nada a dizer" (S:02,08 e 19). 
As categorias obtidas na questão relacionada ao Programa Educativo, serviram para auxiliar na formação da Ação Educativa, bem como com as das categorias obtidas através das questões anteriores, estabelecemos a Ação Educativa de uma maneira dialógica conforme sugerido por alguns idosos entrevistados indo ao encontro com as idéias de Freire e Bueno (1992, 1993, 2001, 2006), que visam constituí-la de uma maneira democrática, vislumbrando a relação de forma horizontal, possibilitando a troca do conhecimento. Dessa maneira aberta, curiosa, indagadora e não apassivada, constituímos a nossa Ação Educativa, da qual os resultados se seguem. 


\section{AÇÃO EDUCATIVA}

Tendo em vista os temas geradores levantados na entrevista por meio dos questionários aplicados aos idosos, bem como pelos dados registrados pela observação participante e da convivência entre pesquisador/ pesquisando, destacamos a importância de trabalharmos conjuntamente com o grupo, os seguintes aspectos: envelhecimento, conceitos de lazer, importância do lazer na saúde, conceitos de turismo, importância do turismo na saúde, os idosos e a saúde mental.

Objetivamos então, trabalhar por meio de dinâmicas de grupo os itens eleitos, na busca da valorização dos mesmos, tendo em vista a melhoria da saúde física e mental do idoso, bem como de seu bem estar social.

\section{TEMA I: ENVELHECIMENTO}

- OBJETIVO: Discutir os aspectos do envelhecimento (Biológico e Psicossocial).

- CONTEÚDO: Discutimos os aspectos do envelhecimento, cada idoso, relatou sua experiência, o que representa a sua vida hoje, como cada um lida com o Envelhecimento e como enfrentam as múltiplas perdas. Nesse momento procuramos trocar nossas idéias e um pouco de nosso conhecimento a cerca do assunto.

- ESTRATÉGIA: Dinâmica de grupo.

- AVALIAÇÃo: Após as discussões, pudemos verificar que muitos dos idosos ali presentes têm total consciência dos problemas decorrentes do envelhecimento, alguns os enfrentam de uma maneira mais positiva, já para outros os impactos são maiores, às vezes decorrentes de sua própria personalidade outras por múltiplos fatores externos. Evidenciamos a importância de um bom enfrentamento para a promoção de sua saúde física, mas sobretudo de sua saúde mental. 


\section{- REFERÊNCIAS BIBLIOGRÁFICAS:}

BALLONE G.J.- Sexo nos Idosos. Disponível em: <http://www.psiqweb.med.br>. Acesso em 18/04/06 às 15:44h.

BEAUVOIR, S. A velhice. Rio de Janeiro: Nova Fronterira, 1990.

CARVALHO, J.A. M.; GARCIA, R.A. O envelhecimento da população brasileira: um enfoque demográfico. Cad. Saúde Pública, v.19, n. 3, p. 725- 733, 2003.

PAPALÉO NETTO, M. Processo de envelhecimento e longevidade In: PAPALÉO NETTO, M. (Org) Tratado de Gerontologia. 2a ed. São Paulo: Atheneu, 2007, p. 3-14.

PASCHOAL, S. M. P.; FRANCO, R. P.; SALLES, R. F. N. Epidemiologia do envelhecimento In: PAPALÉO NETTO, M. (Org) Tratado de Gerontologia. $2^{a}$ ed. São Paulo: Atheneu, 2007, p. 39-56.

RODRIGUES, R. A. P; DIOGO, M.J.D.; BARROS, T.R. O envelhecimento do ser humano In: RODRIGUES, R. A. P; DIOGO, M.J.D (Orgs) Como cuidar dos idosos. $4^{\mathrm{a}}$ ed. Campinas: Papirus, 2004, p. 11-16.

\section{TEMA II: CONCEITOS DE LAZER}

- OBJETIVO: Discutir os conceitos de lazer e de turismo.

- CONTEÚDO: Discutimos os conceitos de lazer e de turismo com o grupo, nesse momento trocamos informações sobre o que é lazer e turismo para cada integrante, como cada um de nós vive essas experiências, as lembranças positivas individuais e como elas fazem parte de nossa história.

- ESTRATÉGIA: Dinâmica de grupo.

- AVALIAÇÃo: Após a realização da dinâmica, verificamos que os idosos têm uma real compreensão do lazer e do turismo, porém essa compreensão ainda poderia ser melhor trabalhada e mais explorada, a medida que eles muitas vezes não reconheciam muitas das atividades de lazer, como tal. Quanto às atividades turísticas essas sim eram mais bem compreendidas.

\section{- REFERÊNCIAS BIBLIOGRÁFICAS:}

BACAL, S. Lazer e o universo dos possíveis. São Paulo: Aleph, 2003. 
BARRETTO, M. Manual de iniciação ao turismo. Campinas: Papirus, 1998.

BUENO, S. M. V. Contribuição ao estudo da aplicação do lazer no ambiente hospitalar. Dissertação (Mestrado) Escola de Enfermagem de Ribeirão Preto, USP, Ribeirão Preto, 1981.

CAMARGO, L. O. L. O que é lazer. São Paulo: Brasiliense, 1999.

DUMAZEDIER, J. Lazer e cultura popular. $3^{\text {a }}$ ed. São Paulo: Perspectiva, 2000.

FERRARI, M. A. C. Lazer, ocupação do tempo livre e os programas da terceira idade In: PAPALÉO NETTO, M. P. (Org) Tratado de Gerontologia. $2^{\mathrm{a}}$ ed São Paulo: Atheneu, 2007, p. 243-251.

FROMER, B.; VIEIRA, D.D. Turismo e terceira idade. São Paulo: Aleph, 2003.

MARCELLINO, N. C. Estudos do lazer. 2a ed. Campinas: Autores Associados, 2000.

\section{TEMA III: A IMPORTÂNCIA DO LAZER E DO TURISMO NA SAÚDE.}

- OBJETIVO: Discutir a importância do lazer e do turismo na educação e na saúde, bem como, discutir e identificar como essas atividades podem ser benéficas para o idoso.

- CONTEÚDO: Encontramos muitos apontamentos positivos em relação ao lazer e ao turismo, como formas para obtenção de saúde física e mental. Os idosos relataram muitas de suas experiências positivas, por exemplo, melhora de suas funções biológicas; obtidas através de atividades físicas de lazer; aumento do ciclo de amizades (PIC); melhora na perspectiva de enxergar o mundo, obtida através das viagens (turismo), aumento da auto-estima, evidenciado principalmente entre as mulheres, entre outros.

- ESTRATÉGIA: Dinâmica de grupo.

- AVALIAÇÃo: Evidenciamos que os idosos realmente se beneficiam do lazer e do turismo, para promoção de sua saúde, trazendo para si uma vida melhor e mais feliz.

\section{- REFERÊNCIAS BIBLIOGRÁFICAS:}

BACAL, S. Lazer e o universo dos possíveis. São Paulo: Aleph, 2003.

BALLONE, G.J. Relatório sobre saúde mental no mundo. Disponível em: <http://www.psiqweb.med.br/acad/oms2.html>. Acesso em: 26/05/05 às 16:20 h.

DUMAZEDIER, J. Lazer e cultura popular. $3^{\text {a }}$ ed. São Paulo: Perspectiva, 2000. 
FERRARI, M. A. C. Lazer, ocupação do tempo livre e os programas da terceira idade In: PAPALÉO NETTO, M. P. (Org) Tratado de Gerontologia. $2^{\mathrm{a}}$ ed São Paulo: Atheneu, 2007, p. 243-251.

MARCELLINO, N. C. Lazer e educação. $2^{a}$ ed. Campinas: Papirus,1990.

\section{TEMA IV: OS IDOSOS E A SAÚDE MENTAL}

- OBJETIVOS: Discutir com os idosos aspectos de sua saúde mental e meios para obtê-la.

- CONTEÚDO: Discutimos o que é saúde mental para cada um, o que significa ser um idoso mentalmente saudável, quais são os impactos da saúde mental no bem estar físico e social, bem como podemos promover a nossa saúde mental.

- ESTRATÉGIA: Dinâmica de grupo.

- AVALIAÇÃo: Após a realização da dinâmica, percebemos que a questão da saúde mental ainda tem muito a ser esclarecida, muitas vezes a ausência de uma patologia é tida como saúde mental, e que os estereótipos estão realmente cristalizados para eles.

Verificamos que para muito dos idosos a busca da saúde mental está em não adoecer somente, o que não é real, embora algumas controvérsias encontradas entre os idosos, a dinâmica possibilitou uma melhor compreensão do que é realmente a saúde mental e como podemos promovê-la. Sendo as atividades de lazer e turismo amplamente citadas nesse momento.

\section{- REFREÊNCIAS BIBLIOGRÁFICAS:}

BALLONE, G.J. Relatório sobre saúde mental no mundo. Disponível em: <http://www.psiqweb.med.br/acad/oms2.html>. Acesso em: 26/05/05 às 16:20 h.

FERRARI, M. A. C. Lazer, ocupação do tempo livre e os programas da terceira idade In: PAPALÉO NETTO, M. P. (Org) Tratado de Gerontologia. 2a ed São Paulo: Atheneu, 2007, p. 243-251.

MUÑOZ, R.; KELLY, J. G. A prevenção das perturbações mentais. São Paulo: Brasiliense, 1978.

NUNES, P.; BUENO, R.; NARDI, A.,G. Psiquiatria e saúde mental. SãoPaulo: Atheneu, 2000. 
PAPALÉO NETTO, M. Processo de envelhecimento e longevidade In: PAPALÉO NETTO, M. (Org) Tratado de Gerontologia. 2a ed. São Paulo: Atheneu, 2007, p. 3-14.

SARACENO, B.; ASIOLI, F.; TOGNONI, G. Manual de saúde mental. São Paulo: Hucitec, 1994.

Entendemos que a Ação Educativa, cumpriu seus objetivos, ao discutir criticamente os temas propostos e favorecendo a conscientização dos integrantes do grupo em torno das temáticas, que nesse caso pode contribuir para a promoção de sua saúde.

Acreditamos que ela se referiu às ações destinadas a melhorar e aprimorar a saúde das pessoas (idosos) não doentes, a questão da Promoção de Saúde, trata-se de um conceito positivo, que deve ser colocado em prática diariamente, como auxílio do desenvolvimento das sociedades (TEIXEIRA, 2002; WHO, 2003). 


\section{CONSIDERAÇÕES FINAIS}

Ao longo desse estudo, pudemos vivenciar um pouco do que é ser um idoso, suas aspirações, dificuldades, dilemas e esperanças. Vivenciamos o cotidiano do PIC, suas atividades e sua rotina, a maneira como tudo funciona.

Encontramos uma população hospitaleira e acolhedora, que nos possibilitou a viagem rumo à sua compreensão, mesmo que parcialmente, isso nos propiciou conhecer um pouco mais do universo do idoso, algo tão particular desconhecido até então.

Verificamos que se trata de uma população realmente ativa socialmente, possuem um bom grau de relacionamento interpessoal. A atividade grupal realmente os proporciona amizade, companheirismo e troca de experiências. Algo muito importante, pois possibilita ao idoso a construção de uma vida em comum, possibilita a formação e estreitamento de laços afetivos, algo tão importante ao longo da vida.

De acordo com os objetivo traçados no início desse estudo, relacionado ao significado do lazer para o idoso, pudemos verificar que os idosos entrevistados têm consciência do que é o lazer e o turismo, bem como, relacionaram essas atividades ao bem-estar e a felicidade.

No entanto, muitas vezes obtivemos respostas superficiais sobre a temática, diante da magnitude dessas atividades, descritas por nós anteriormente. Sendo necessário uma melhor explanação e maiores esclarecimentos a respeito do assunto, bem como um maior entendimento por parte dos idosos. Eles apontaram isso na questão voltada à formação de nossa Ação Educativa, que estava relacionada com o nosso segundo objetivo, justamente de trocarmos nossas informações com os idosos, a respeito dos tópicos levantados por eles e pelas categorias encontradas nas repostas obtidas através da entrevista.

Relataram ainda, que se distraem muito durante a realização das atividades de lazer, que são as atividades de sua preferência, em contrapartida as atividades que menos gostam, 
englobam as categorias dos aspectos ocupacionais, ociosidade e solidão. Ainda preconizam que ao fazer lazer e viajar, sentem-se muito bem, com sentimentos relacionados à alegria, felicidade, tranqüilidade e bem- estar, entendemos então, que ali reside a promoção de sua saúde mental.

Identificamos que eles em sua maioria gostam de viajar, viajam com certa freqüência, acompanhados por familiares e amigos, porém nem sempre têm oportunidade, mas pensam em viajar em um futuro próximo.

Para os idosos pesquisados a amizade é demasiadamente importante, ao passo que os afastam do isolamento social e de todas as complicações que ele acarreta, o PIC é para eles um meio de afastá-los desse isolamento. Ao contrário disso aumenta seus ciclos de amizade, contribuindo para seu bem-estar social.

Quanto aos estressores da vida contemporânea, como a violência, que por vezes alteram a saúde mental das pessoas, os idosos questionados referem à violência com sentimento de medo, de algo ruim, que gera tristeza e preocupação.

Além disso, a violência é um dos fatores que pode influenciar em suas atividades de lazer, visto o perigo que pode representar, questionados quanto a isso, os idosos referem que realmente se preocupam e que isso pode sim prejudicar o seu lazer. E que se pudessem tomariam ações para evitá-la, ligadas principalmente à Educação e religião.

Percebemos que os idosos alegram-se com as atividades de lazer, com a proximidade dos familiares, amigos, religião e destacam a grande importância em ter uma boa saúde em suas vidas.

Os idosos ainda sonham muito, principalmente com uma boa velhice, com saúde e felicidade para cada um e de seus familiares. Acreditam que suas vidas significam uma bênção divina, muitos traduzem suas vidas em sentimentos positivos, felicidade, maravilha e coisas boas. 
É importante destacar a importância que eles atribuem ao PIC, eles o citam por todo o tempo, no momento em que estiveram livres para se expressar atribuíram sentimentos positivos ao grupo.

Já a Ação Educativa, que foi de extrema importância em nosso estudo, com a troca de conhecimento, a visão do outro, a reflexão e o respeito, somados na busca da construção coletiva do conhecimento, nos possibilitou uma experiência única, pudemos trabalhar a questão do lazer e do turismo, que conforme dito anteriormente, para alguns a visão a respeito dessas atividades era superficial, devido a sua importância.

Trabalhamos também a questão do envelhecimento, e da saúde mental, trocamos informações e relatos de experiências nessas atividades grupais.

Compreendemos um pouco mais da importância desse grupo em suas vidas, o quão algumas reuniões, atividades e práticas parecem para muitos algo simples, sem sentido, mas o quanto isso pode significar para os indivíduos envolvidos, nesse caso os idosos.

Entendemos que essa comunidade realmente sabe o que deseja e o que lhes faz bem, o que é importante para si. Mas, além disso, entendemos que eles gostam e valorizam as atividades de lazer e turismo, ali desenvolvidas e proporcionadas, vivenciam bem o seu envelhecimento e acreditam que isso reflete na promoção de sua saúde física e sobretudo sobre a sua saúde mental. 


\section{REFERÊNCIAS BIBLIOGRÁFICAS}

ANDRADE, J.V. Gestão em lazer e turismo. Belo Horizonte: Autêntica, 2001.

ARAÙJO, S.M. Artifício e Autenticidade: o turismo como experiência antropológica In BANDUCCI,Á. Jr. BARRETO, M (Orgs.). Turismo e identidade local: uma visão antropológica .Campinas: Papirus, 2001.p.49- 63.

AVIGHI, C.M. Turismo, globalização e cultura In LAGE, P.MILONE, C. (Orgs.).Turismo:Teoria e prática : São Paulo:Atlas, 2000, p102-106.

BACAL, S. Lazer e o universo dos possíveis. São Paulo: Aleph, 2003.

BALLONE, G.J. Relatório sobre saúde mental no mundo. Disponível em:

$<$ http://www.psiqweb.med.br/acad/oms2.html>. Acesso em: 26/05/05 às 16:20 h.

BALLONE G.J - Sexo nos Idosos. Disponível em: <http://www.psiqweb.med.br>. Acesso em 18/04/06 às 15:44h.

BANDUCCI, A. Jr. Turismo e Antropologia no Brasil In: BANDUCCI, A. Jr. BARRETO, M (Orgs.) Turismo e identidade local: Uma visão antropológica. Campinas: Papirus, 2001, p.21-45.

BARRETTO, M. Manual de iniciação ao turismo. Campinas: Papirus, 1998.

BENI, M. C. Análise estrutural do turismo. São Paulo: SENAC, 1998.

BEAUVOIR, S. A velhice. Rio de Janeiro: Nova Fronteira, 1990.

BUENO,S. M. V. Contribuição ao estudo da aplicação do lazer no ambiente hospitalar. Dissertação (Mestrado) Escola de Enfermagem de Ribeirão Preto, USP, Ribeirão Preto, 1981.

BUENO,S. M. V. Educação preventiva em sexualidade, DST-AIDS e drogas nas escolas. Livre Docência Escola de Enfermagem de Ribeirão Preto, USP, Ribeirão Preto, 2001.

CAMARGO, L. O. L. O que é lazer. São Paulo: Brasiliense, 1999.

CARVALHO, J.A. M.; GARCIA, R.A. O envelhecimento da população brasileira: um enfoque demográfico. Cad. Saúde Pública, v.19, n. 3, p. 725- 733, 2003.

DE LA TORRE, O. El turismo, fenômeno social. México: Fondo de Cultura Econômica, 1992.

DIAS,V. K.; SCHWARTZ, G.M. O lazer na perspectiva do indivíduo idoso. Revista Digital de Buenos Aires, Disponível em:< http://www.efdeportes.com/efd87/idos.htm> Acesso em $09 / 07 / 07$ as $15: 17$. 
DUMAZEDIER, J. Lazer e cultura popular. 3ª ed. São Paulo: Perspectiva, 2000.

FERRARI, M. A. C. Lazer, ocupação do tempo livre e os programas da terceira idade In: PAPALÉO NETTO, M. P. (Org) Tratado de Gerontologia. 2a ed São Paulo: Atheneu, 2007, p. 243-251.

FREIRE, P. Pedagogia do oprimido. 22ª ed. São Paulo: Paz e Terra, 1992.

FREIRE, P. Política e Educação: ensaios. Rio de Janeiro: Paz e Terra, 1993.

FREIRE, P. Pedagogia da autonomia: saberes necessários à prática educativa. $34^{\mathrm{a}}$ edição São Paulo: Ed. Paz e Terra, 2006.

FROMER, B.; VIEIRA, D.D. Turismo e terceira idade. São Paulo: Aleph, 2003.

GASPARI, J.C; SCHWARTZ, G.M. O idoso e a ressignificação emocional do lazer. Psicologia Teoria e Pesquisa, v.21 n.1, p. 69-76, 2005.

IGNARRA, L. R. Fundamentos do turismo. São Paulo: Pioneira Learning, 2003.

INSEL,M.P.; ROTH, W. T. Core concepts in health. 10ª ed. Nova York, 2006.

LIMA-COSTA, M. F.; VERAS, R.P. Saúde pública e envelhecimento. Cad. Saúde Pública , Rio de Janeiro,v. 19, n. 3, p. 700-701, 2003.

MAIA, L. C.; DURANTE, A. M G; RAMOS, L. R. Prevalence of mental disorders in an urban area in Brazil. Rev. Saúde Pública, São Paulo, v. 38, n. 5, p. 650-656, 2004.

MARCELLINO, N. C. Estudos do lazer. 2a ed. Campinas: Autores Associados, 2000.

MARCELLINO, N. C. Lazer e educação. $2^{\text {a }}$ ed. Campinas: Papirus,1990.

MINAYO, M. C. S. O desafio do conhecimento: pesquisa qualitativa em saúde. São PauloRio de Janeiro: Hucitec-Abrasco, 1992.

MOREIRA-ALMEIDA, A.; LOTUFO NETO, F.; KOENIG, H. G. Religiouness and menthal health: a review. Rev. Bras. Psiquiatria., v.28, n.3, p.242-250, 2006.

MOYSES, S. J.; MOYSES, S. T.; KREMPEL, M. C. Assessing the building process of health promotion public policies: the experience of Curitiba. Ciênc. saúde coletiva , Rio de Janeiro, v. 9, n. 3, p. 627-641, 2004.

MUÑOZ, R. ; KELLY, J. G. A prevenção das perturbações mentais. São Paulo: Brasiliense, 1978.

NETO, O. C. O. Trabalho de campo como descoberta e criação In: MINAYO, M. C. S. (Org.) Pesquisa social teoria, método e criatividade. Petrópolis: Vozes, 1994, p. 51-66.

NUNES, P.; BUENO, R.; NARDI, A.,G. Psiquiatria e saúde mental. SãoPaulo: Atheneu, 2000. 
PAIVA, M. G. M. V. Sociologia do turismo. $7^{\text {a }}$ ed. Campinas: Papirus, 2001.

PALHA, P. F.; LIMA, G. M.; MENDES, I. J. M.. Programa de integração comunitária: em busca de novas estratégias e novos sentidos à vida. Rev. Latino-Am. Enfermagem, Ribeirão Preto, v. 8, n. 2, p. 5-10, 2000.

PAPALÉO NETTO, M. Processo de envelhecimento e longevidade In: PAPALÉO NETTO, M. (Org) Tratado de Gerontologia. 2a ed. São Paulo: Atheneu, 2007, p. 3-14.

PASCHOAL, S. M. P.; FRANCO, R. P.; SALLES, R. F. N. Epidemiologia do envelhecimento In: PAPALÉO NETTO, M. (Org) Tratado de Gerontologia. $2^{a}$ ed. São Paulo: Atheneu, 2007, p. 39-56.

IBGE. Perfil dos idosos responsáveis pelos domicílios no Brasil, 2000. Disponível em:<http://www.ibge.gov.br/home/estatistica/populacao/perfilidoso/perfidosos2000.pd> Acesso em: 21/11/06 as 14:42 h.

PESSOTTI, I. A loucura e as épocas. 2ª ed. Rio de Janeiro: Ed. 34, 1994.

PUEL, E. et al. Saúde mental: transpondo as fronteiras hospitalares. Porto Alegre: Da Casa, 1997.

REQUIXA, R. Sugestões de diretrizes para uma política nacional de lazer. SESC. São Paulo, 1980.

RODRIGUES, R. A. P; DIOGO, M.J.D.; BARROS, T.R. O envelhecimento do ser humano In: RODRIGUES, R. A. P; DIOGO, M.J.D (Orgs) Como cuidar dos idosos. $4^{\mathrm{a}}$ ed. Campinas: Papirus, 2004, p. 11-16.

RUIPEREZ, I.; LLORENTE, P. Guias práticos de enfermagem geriátrica. Trad. Maria Teresa Ramalhal Teixeira. Rio de Janeiro: Mc Graw- Hill Interamericana, 2001.

SANTOS FILHO, J. Ensaio Sociológico sobre o fenômeno do lazer em Karl Marx e Paul Lafargue. Turismo em Análise, v.15, n. 2, p. 150-165, 2004.

SARACENO, B.; ASIOLI, F.; TOGNONI, G. Manual de saúde mental. São Paulo: Hucitec, 1994.

TEIXEIRA, M. B. Empoderamento de idosos em grupos direcionados à promoção da saúde. Dissertação (Mestrado) Fundação Oswaldo Cruz, Escola Nacional de Saúde Pública. Rio de Janeiro, 2002.

THIOLLENT, R. P. Metodologia da pesquisa ação. 14 ed. São Paulo: Cortez, 2005.

TRIGO, L. G. G. Turismo básico. 5a ed. São Paulo: Apontamentos Turismo, 1998.

URRY, J. O olhar do turista- lazer e viagens nas sociedades contemporâneas. São Paulo: SESC/Nobel, 1990. 
VERAS, R. P. País jovens com cabelos brancos: a saúde do idoso no Brasil. Rio de Janeiro: Relume Dumará, UERJ, 1994.

VERAS, R.P. Fórum envelhecimento populacional e as informações de saúde do PNAD: demandas e desafios contemporâneos. Introdução. Cad. Saúde Pública, v. 23, n 10, p. 24632466, 2007.

WHO. A saúde mental pelo prisma da saúde pública. Disponível em : <http://www.who.int/whr/2001/en/whr01_ch1_po.pdf>. Acesso em 06/04/07 as 15:11 h.

WHO. Repercussão da violência na saúde das populações americanas. Disponível em :

$<$ http://www.ops-oms.org/portuguese/gov/cd/cd44-01-p.pdf >. Acesso em 05/07/07 as 17:17 h 


\section{APÊNDICES}

\section{APÊNDICE 1}

Questionário Informativo

A- DADOS SÓCIO DEMOGRÁFICOS:

1.N': 2. Idade:__ 3. Sexo: ___ Religião:

5. Estado Civil:___ 6. Escolaridade

7. Profissão 8. Renda Mensal

9. Tem Filhos 10.Quantos 11. Tem Netos 12.Quantos

B- DADOS SOBRE LAZER, TURISMO E SAÚDE MENTAL

1. O que é lazer?

2. O que é turismo?

3. Você se distrai? Sim( ) Não ( ) Como?

4. O que você mais gosta de fazer?

5. O que você menos gosta de fazer?

5. Quando você se distrai com o que você gosta, como se sente?

6. Quando faz lazer e viaja, a cabeça como fica?

7. Você tem viajado?_Com quem?( )família ( )amigos ( ) outros

8. Você viaja com que freqüência?( )muito ( ) pouco ( )nunca

9. Esse ano já viajou?___E para o próximo ano pensa em viajar?

10. O que significa a amizade para você?

11. Como você tem visto a violência hoje?

12. Isto prejudica o seu lazer?

13. O que você faria para evitar essa violência?

14. Você gosta de música?

15. Você gosta de dança?

16. O que traz alegria para você?

17. O que significa sua vida hoje?

18. O que você sonha para si?

19. Livre para você falar o que quiser:

C- PROGRAMA EDUCATIVO:

1. O que você gostaria que eu falasse com você sobre o assunto de lazer e turismo, como educação para a sua saúde física e mental. E de que forma poderíamos trabalhar juntos essa questão? 


\section{APÊNDICE 2}

\section{TERMO DE CONSENTIMENTO LIVRE E ESCLARECIDO}

Eu, Cynthia Daniela Figueiredo de Souza, aluna da Pós-Graduação do Departamento de Enfermagem Psiquiátrica e Ciências Humanas da Escola de Enfermagem de Ribeirão PretoUSP, estou realizando um trabalho para identificar a importância do lazer e do turismo na vida de idosos que freqüentam o PIC (Programa de Integração Comunitária). Bem como planejar, executar e avaliar conjuntamente com vocês, atividades educativas voltadas ao conhecimento e importância do lazer e do turismo, em suas vidas, orientando- os para a necessidade de promoção de sua saúde mental.

Este estudo será realizado através de uma entrevista que não será gravada, vou utilizar um questionário com questões norteadoras, você deverá responder trinta e três perguntas. Tudo que você disser será utilizado somente nesse trabalho. Em momento algum, você será identificado(a).Depois que você responder essas questões, em um dia específico eu retornarei até aqui, no local onde você realiza suas atividades: no Centro Social Urbano(CSU)- Vila Virgínia, para realizarmos uma atividade educativa, que acontecerá no salão coberto nesse mesmo local, onde nesse momento trabalharemos questões voltadas ao lazer e ao turismo, respondendo dúvidas, dando informações e buscando uma melhor compreensão da importância dessas atividades para sua saúde física e mental.Mesmo após o início de nossas conversas, você poderá desistir, a qualquer momento, caso não esteja se sentindo a vontade ou não concorde mais em participar do trabalho. Se você desistir de participar do estudo, você não será prejudicado(a) e continuará participando das atividades do programa.Nossos encontros começarão em Novembro e acontecerão provavelmente até inicio de Dezembro quando termina meu tempo de trabalho com vocês; esses encontros acontecerão no local onde você realiza suas atividades.Peço também o consentimento para tirar algumas fotos de caráter meramente ilustrativo.Se você aceitar participar desse trabalho estará contribuindo para que se aprenda e saiba um pouco mais sobre a importância do turismo. Por esse motivo, os resultados dessa pesquisa serão divulgados e publicados para a orientação e promoção de saúde mental em pessoas com a mesma idade, visando à qualidade de vida delas.

Diante de tudo que foi dito e esclarecido pela pesquisadora, eu concordo em participar voluntariamente dessa pesquisa, recebendo uma cópia desse termo, para possível contato se for necessário.

Nome do Participante. RG

Assinatura do Participante.

Assinatura do Pesquisador.

Fone para contato: (16) 3621- 3230 / (16) 9203-6686 de $2^{\mathrm{a}}$ a $6^{\mathrm{a} .}$ feria das 08:00h às 17:00 h Endereço: Rua Cerqueira César, 2362 - Sumaré.

E-mail: souza_rao@yahoo.com.brRibeirão Preto, de de 2006 


\section{ANEXO}

\section{ANEXO A \\ PARECER DO COMITÊ DE ÉTICA}
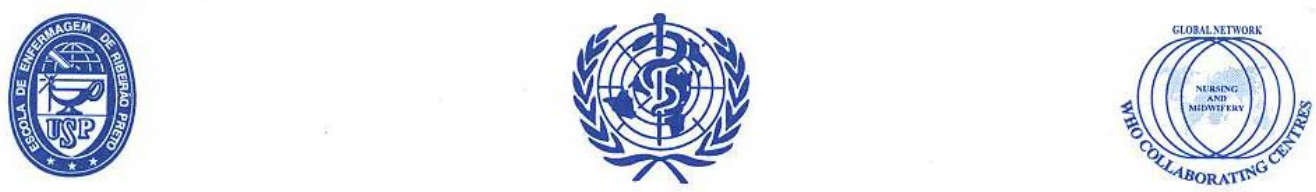

ESCOLA DE ENFERMAGEM DE RIBEIRÃO PRETO - UNIVERSIDADE DE SÃO PAULO

CENTRO COLABORADOR DA ORGANIZAÇÃO MUNDIAL DA SAÚDE PARA

O DESENVOLVIMENTO DA PESQUISA EM ENFERMAGEM

Avenida Bandeirantes, 3900 - Campus Universitário - Ribeirão Preto - CEP 14040-902 - São Paulo - Brasil FAX: (55) - 16 - 3633-3271 / 3602-4419 / TELEFONE: (55) - 16 - 3602-3382

COMITÊ DE ÉTICA EM PESQUISA DA EERP/USP

Of.CEP-EERP/USP - 210/2007

Ribeirão Preto, 10 de outubro de 2007

Prezada Senhora,

Comunicamos que o projeto de pesquisa, abaixo especificado, foi analisado e considerado APROVADO AD REFERENDUM pelo Comitê de Ética em Pesquisa da Escola de Enfermagem de Ribeirão Preto da Universidade de São Paulo, em 20 de dezembro de 2006.

Protocolo:

$n^{\circ} 0728 / 2006$

Projeto:

LAZER E TURISMO NA INTERFACE DA SAÚDE E DA EDUCAÇÃO COMO MEIO DE PROMOÇÃO DE SAÚDE MENTAL DO IDOSO

Pesquisadores: Sônia Maria Villela Bueno

Cyntia Daniela Figueiredo de Souza

Em atendimento à Resolução 196/96, deverá ser encaminhado ao CEP o relatório final da pesquisa e a publicação de seus resultados, para acompanhamento, bem como comunicada qualquer intercorrência ou a sua interrupção.

Atenciosamente,

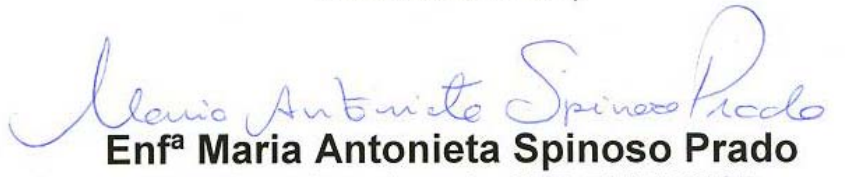

Vice-Coordenadora do CEP-EERP/USP

$\mathrm{IIm}^{\mathrm{a}}$. Sr ${ }^{\mathrm{a}}$.

Profa. Dra ${ }^{\mathrm{a}}$. Sônia Maria Villela Bueno

Departamento de Enfermagem Psiquiátrica e Ciências Humanas

Escola de Enfermagem de Ribeirão Preto-USP 